\title{
Ideology and redistribution through public spending
}

\author{
Helmut Herwartz ${ }^{\mathrm{a} *}$ and Bernd Theilen ${ }^{\mathrm{b} \dagger}$
}

August 7, 2015

\begin{abstract}
For a panel of OECD economies (1980-2013) we analyse the scope of government ideology to shape patterns of public expenditures. To address if public expenditures are used to channel redistributive outcomes, we adopt a flexible panel error correction model and proceed in two steps: Firstly, we analyse if ideological positions matter for the sizing of the public sector. Secondly, we address the actual impact of government ideology on two disjoint categories of public expenditure that are characterized by distinguished redistributive effects. Under both, left-wing and right-wing governments, public spending shows progressively redistributive effects which are indirectly channelled through their policy response to changing macroeconomic, fiscal and demographic fundamentals. While right-wing governments act progressively redistributive under favourable socio-economic conditions, their left-wing counterparts do so under unfavourable conditions. Comparing the two effects in terms of their explanatory content, the latter is found stronger than the former.
\end{abstract}

JEL classification: H53, H87, I18, D72, F13, F60, C22, C23

Key words: Redistribution; Public expenditure; Government ideology; Electoral cycles; OECD panel data

${ }^{a}$ Department of Economics, Georg-August-University Göttingen, Germany, E-mail: hherwartz@unigoettingen.de

${ }^{\mathrm{b}}$ Departament d'Economia and CREIP, Universitat Rovira i Virgili, Spain, E-mail: bernd.theilen@urv.es

*The author declares that he has no relevant or material financial interests that relate to the research described in this work.

${ }^{\dagger}$ Bernd Theilen gratefully acknowledges financial support from the Spanish Ministerio de Ciencia e Innovación under project ECO2013-42884-P. The author declares that he has no relevant or material financial interests that relate to the research described in this work. Both authors gratefully acknowledge support by Yabibal M. Walle providing panel unit root and cointegration diagnostics. 


\section{Introduction}

A central aspect of political programmes of left-wing parties is the reduction of inequality in income distribution. ${ }^{1}$ Historically, this objective has been primarily achieved through changes in the tax structure. However, since the early 1980s with the liberalization of goods and capital markets, most governments have reduced top marginal income and capital tax rates as a response to the globalization process. ${ }^{2}$ A consequence of this process is that political parties have lost most of their influence on tax policies. Indeed, numerous recent studies have shown that party ideology has no significant influence on the progressiveness of tax systems (Volkerink and De Haan 1999, Galli 2002, Swank and Steinmo 2002, Cusack and Baramendi 2006). Instead, it has been argued that, nowadays, parties pursue welfare redistribution mainly through putting emphasis on distinguished spending policies that favour more than proportionally low income earners such as health care, unemployment, and social spending in general and not through changes in the tax structure. $^{3}$ Thus, in the mid-2000s, the average redistributive effect in OECD countries achieved through public social spending was already twice as large as that achieved through income taxation (OECD 2008, 2011; Wang et al. 2012, 2014).

From these findings we would expect that left-wing parties, which advocate more income redistribution in party manifestos than their right-wing counterparts, promote higher spending in public expenditure categories that primarily benefit low income earners. However, recent studies have shown only a muted effect of party ideology, for example, on social expenditure (Iversen 2001, Kittel and Obinger 2003, Potrafke 2009, Herwartz and Theilen 2014a) or health expenditure (Potrafke 2010, Herwartz and Theilen 2014b) after the 1990s. Furthermore, right-wing parties are, generally, more in favour of a reduced public sector and, therefore, aim to limit overall public expenditure (see e.g. Hibbs 1977, 1987, Cameron 1978, Alesina 1987, Cussack 1997, De Donder and Hindriks 2007, Pickering and Rockey 2011). Therefore, more social spending of left-wing parties only testifies their larger preference for social justice, if it does not come along with more spending in other expenditure categories featuring redistributive effects that go into the opposite direction.

The objective of our study is to analyse if party ideology has a distinguishable effect on redistributive justice. For this purpose we adopt a two-step approach. In the first step, we analyse the socio-economic and political determinants of public expenditure. In the second step, we analyse the impact of government ideology on redistributive spending by decomposing public expenditure in two disjoint categories: social spending and 'nonsocial' spending. Social spending comprises, among other categories, health care, old age, survivors, incapacity-related benefits, family programmes, active labour market pro-

\footnotetext{
${ }^{1}$ See Bradley et al. (2003) for an overview of distribution and redistribution in modern societies and the (expected) decisive role of leftist governments.

${ }^{2}$ As pointed out by Peter et al. (2010), the GPD-weighted average top statutory marginal personal income tax rate in a sample of 189 countries has fallen from more than $60 \%$ at the beginning of the 1980 s to less than $40 \%$ in 2005 . Overall, progressiveness of tax schemes has also declined. A similar downward convergence of tax rates over this period can be observed in capital taxation where the $(24$ OECD countries' average central government) corporate top statutory tax rate has decreased from $42 \%$ in 1980 to $25 \%$ in 2012 (Chengrui 2014).

${ }^{3}$ That such a redistributive public spending can effectively redistribute income has been shown, e.g., by Afonso et al. (2010).
} 
grammes, unemployment benefits, and housing programmes. Social spending is equivalent to a progressive welfare redistributive, as more social spending more than proportionally benefits low income earners. ${ }^{4}$ 'Non-social' spending comprises, for example, expenditure on education, infrastructure, security and administration. Higher expenditures on these categories more than proportionally favour the middle and upper income classes such that public spending on the 'non-social' spending categories is more regressive compared with social expenditure. The adopted two-step approach has two advantages. First, it reflects the political decision process that first determines the size of the total budget and, then, decides on its distribution on different spending categories (top-down budgeting). Secondly, it allows to separate ideologically motivated adjustments of the size of the public sector from ideologically motivated prioritization of specific spending programmes.

The framework adopted in this study allows to analyse three questions that have not been addressed previously in the literature:

Q1: Does ideology (and other political variables such as the timing of elections, the polarization of the party system or the number of coalition partners) influence progressively redistributive public spending?

Q2: Do parties react differently to social and economic changes?

Q3: Do these reactions have distinguished effects on social and 'non-social' public spending?

The first question emphasizes that differences in social expenditure between parties of different ideologies do not necessarily reflect differences in their wish to redistribute income when they are accompanied by similar differences in other spending categories. In such a case, they rather indicate divergent party positions regarding the total size of the public sector. With the first question (Q1) we analyse if government ideology and other political variables have a direct redistributive impact on distinguished spending categories. With the second question (Q2) we want to take account of the fact that party ideology does not necessarily impact directly on public spending. Rather it can impact indirectly through the channel of distinct reactions of parties to changes in the socio-economic environment. This is because parties might adjust public expenditure in different ways over the business cycle, and react differently to changes in the population structure, changes in the size of government deficits, or in the level of public debt. We respond to this question by thoroughly analysing the interaction effects of party ideology with several socio-economic variables. With the third question (Q3) we explore if the before-mentioned indirect channel of party ideology on public expenditure works differently for social and 'non-social' expenditure. We respond to this question by comparing the interaction effects of party ideology with our socio-economic variables on social expenditure with those they have on 'non-social' expenditure.

Related studies have focused on specific spending categories or the determinants of the composition of public spending. These studies are mostly based on cross-sectional

\footnotetext{
${ }^{4}$ For example, see Hicks and Swang (1992) for an overview on the literature regarding the link between party ideology, voter preferences and welfare spending.
} 
data analysis and have underscored the importance of differences in the political institutional settings (e.g., Persson and Tabellini 1999, Persson et al. 2007), income distribution (Meltzer and Richards 1981, Shelton 2007), or ethnical fractionalization (Alesina et al. 1999, Shelton 2007) to explain cross-country differences in public spending patterns. ${ }^{5}$ However, once such types of 'country-specific factors' are allowed for, the impact of different ideological positions of governments in different countries can be hardly distinguished in cross-sectional studies. Therefore, as the objective of this study is to identify the impact of changes in government composition on redistributive spending, we take especially account of country-specific time patterns of public spending composition. Our analysis is based on data from 21 OECD economies over the period 1980-2013. As a particular merit, the considered panel dimension allows to figure out how ideology matters in government responses to macroeconomic conditions and demographic patterns that are subject to both cross-sectional and time variation. Noting that the considered time period covers several business cycles, the sample information is likely rich on information how governments holding diverse ideological positions cope with more or less favourable domestic socio-economic performance. Moreover, the framework of the adopted panel error correction model (ECM), or cointegration model, allows to distinguish between long-run and short-run determinants of public spending. While the former include demographic and economic trends (e.g., population ageing, globalization, government indebtedness), political factors exclusively belong to the second class of determinants. Long-run determinants of public spending are used to indicate stances of an oversized (positive equilibrium error) or undersized public sector (negative equilibrium error). Short-term adjustments of public spending in the ECM (partly) respond to deviations of the size of the public sector from its presumed equilibrium. Such indicators of an eventually oversized or undersized public sector might induce ideology dependent policy responses which can be incorporated into the empirical model by means of suitable interaction variables. To address the redistributive nature of public spending it is tempting, moreover, to distinguish adjustments of social and 'non-social' expenditures in response to violations of the equilibrium supposed to hold at the level of overall public spending. In the empirical analysis, we formalize respective 'quasi ECMs' where deviations from the fundamental size of the public sector govern expenditure adjustments in disjoint spending categories. The empirical model thereby copes with two particularly important features in the determination of public budgets: it distinguishes between long-run and short-run determinants of its total size, and it separates the short-run influences on budget size from those on budget composition.

With regard to the first question (Q1), our results indicate that ideological government positions, the polarization of the party system and the number of coalition partners have no distinguished direct influence on social and 'non-social' spending. However, electoral cycles observed for general public spending turn out to be redistributive as they are only present in social spending but not in 'non-social' spending. We take this result as evidence for the prevalence of distributional issues during election campaigns. Responding to the second question (Q2), we obtain that the influence of ideological government positions on

\footnotetext{
${ }^{5}$ Though some studies are based on panel data, the time series dimension of the data is not fully explored in the analysis. For example, Shelton (2007) builds five-year averages such that his 31 annual observations per country are transformed into 6 observation per country.
} 
public spending comes through the channel of distinct reactions of left-wing and rightwing coalitions to varying macroeconomic, fiscal and demographic conditions. Finally, for the third of our questions (Q3), we diagnose redistributive spending channelled through governments' policy responses to these changing conditions under both, left-wing and right-wing coalitions. Remarkably, while right-wing governments increase social spending and thereby act progressively redistributive under favourable demographic and macroeconomic conditions, left-wing governments do so under unfavourable conditions. Comparing the two effects, our results indicate that the latter is stronger than the former.

Section 2 relates our study to the literature. Section 3 describes the data and the empirical model. In Section 4 we provide a discussion of our empirical results. Section 5 concludes. In the Appendix we are explicit on unit root and cointegration diagnostics, and on the relation between public expenditure and its long term fundamental determinants.

\section{Public spending and ideology: what do we know?}

Political effects on public spending and its components have been documented since Cameron (1978). The literature has distinguished mainly between the effects of ideology and electoral cycles, but has also considered other political factors such as the number of coalition partners, the fractionalization and polarization of the government and the party system, or the type of the electoral system.

\section{$2.1 \quad$ Ideology}

The influence of party ideology on public spending and the size of the public sector has been explained in the literature by the partisan approach which states that, as a response to heterogeneous voter preferences, politicians pursue policies that reflect the preferences of their partisans. ${ }^{6}$ It is argued that left-wing parties favour policies that redistribute income from the rich to the poor to attract votes from low income earners. This leads to larger social spending and public expenditure in general. Instead, right-wing parties emphasize the inefficiencies of the public sector and, therefore, promote policies that deregulate the public sector and reduce public expenditure. In line with these arguments Cameron (1978) and, more recently, Cusack (1997) confirm a larger growth rate of public expenditure under left-wing governments than under their right-wing counterparts.

An influence of party ideology on distinct components of public budgets has also been extensively documented in the literature. Regarding social expenditure, Hicks and Swank (1992), Kittel and Obinger (2003), Bräuninger (2005), Potrafke (2009) and Herwartz and Theilen (2014a) find that left-wing parties spend more than right-wing parties on social issues. The more recent studies have shown, however, that the influence of party ideology has decreased over time which has been addressed to a general institutional change that took place in the early 1990s, and that can be explained by the creation of new supranational institutions, and strengthened integration of goods and capital markets (Herwartz and Theilen 2014a). Similar tendencies have been shown, for example, for health care

\footnotetext{
${ }^{6}$ This should even be the case with self-interested politicians that pursue their own interest because of reputation (see Bowler et al. (2006) for empirical evidence on this).
} 
expenditure (Potrafke 2010, Herwartz and Theilen 2014b), pension expenditure (Tepe and Vanhuysse 2009), or education expenditure (Potrafke 2011, Jensen 2011).

The recent literature has also analysed the influence of party ideology on the composition of public budgets. ${ }^{7}$ Tsebelis and Chang (2004) find, on the one hand, that the larger is the difference in the ideological position of successive governments, the more significant are the changes in the structure of public budgets. On the other hand, they show that the larger the 'ideological distance' of government coalitions is, the less the structure of public budgets is changed. Brender and Drazen (2013) focus on the effects of the replacement of party leaders on the composition of government spending. They obtain that leaders' replacements have no significant short-run effect on expenditure composition. In the medium term (after three to four years), leadership changes involve larger changes in expenditure composition in developed countries. However, ideological motives for such changes in budget composition are not analysed in their paper.

Finally, an important issue raised in the recent literature is the endogeneity of party ideology in the determination of party influence for economic outcomes. Petterson-Lidbom (2008) uses a regression discontinuity approach initial applied by Lee et al. (2004) to control for endogeneity of candidates' policy choices in the U.S. House of Representatives and finds an party ideology influence for Swedish local governments on local taxation and unemployment. Folke (2014) also using data for Swedish municipalities, uses the same approach to analyse the effect of small parties on immigration, environmental and tax policy and obtains a large effect on the first two policies but not on tax policy. Gerber and Hopkins (2011) analyse the impact of mayors' partisanship on policy outcomes for U.S. cities. Using regression discontinuity design, they find that Democratic mayors spend more on public safety than Republican or Independent mayors while for other policy areas (with overlapping federal and state government authority) no differences are obtained.

\subsection{Electoral cycles}

It has been commonly recognized that before elections incumbent politicians raise public spending to increase their reelection probabilities. This kind of opportunistic behaviour is independent of ideological platforms, and leads to a politically motivated business cycle. Theoretically, this phenomenon has been explained by irrational backward-looking agents (Nordhaus 1975), or by rational agents with asymmetric information (e.g. Rogoff and Sibert 1988, Alesina at al. 1997, Persson and Tabellini 2000). In empirical studies, political business cycles have been documented for total public expenditure in developed economies (e.g. Alesina et al. 1997, Persson and Tabellini 2000), or for expenditure categories like social expenditure (Herwartz and Theilen 2014a), or health care expenditure (Potrafke 2010, Herwartz and Theilen 2014b). ${ }^{8}$

\footnotetext{
${ }^{7}$ Neglecting ideological aspects, some authors also have studied the relationship between budget composition and socio-economic processes such as population ageing or globalization. Sanz and Velazquez (2007) find that ageing is one of the main driving forces of the growth of overall government spending but also for social welfare, health care and defence expenditure. Shelton (2007) highlights also the contribution of trade openness to total expenditure growth. Dreher et al. (2008), Gemmell et al. (2008), and Shelton (2007) find that globalization has no significant influence on government budget composition.

${ }^{8}$ See also Brender and Drazen (2005) for a review of the literature on political budget cycles.
} 
Effects of electoral cycles on the composition of spending have been explained by Rogoff (1990) and Drazen and Eslava (2010). They argue that shifts in public expenditure from one spending category to another spending category allow incumbents to signal either their competence or their preferences to the electorate. Empirically, election motivated expenditure shifts have been documented by Katsimi and Sarantidis (2012). They find that (predetermined) elections shift public spending towards current expenditures at the cost of public investment, while they do not affect overall government expenditure. Brender and Drazen (2013) find that elections in developed countries are associated with larger shifts in the composition of public expenditure. ${ }^{9}$

\subsection{Other political influences}

The literature has also highlighted a number of other political factors that influence public spending. Persson et al. (2007) show in a theoretical model that government spending increases with the number of coalition partners. Thus, overall government spending is larger under coalition governments than under single-party governments. Empirically this prediction is confirmed, e.g., by the same authors and by Perotti and Kontopoulos (2002). On the contrary, the veto player theory predicts that when the number of coalition partners (veto players) increases, departures from the status quo are less likely (Tsebilis 1995, Tsebelis and Chang 2004). From this prediction we would expect smaller changes in government expenditure with more coalition partners.

Azzimonti (2011) develops a political economy model showing that the degree of polarization of the party system affects political decision making in equilibrium. Incumbents finance overspending with distortionary taxes to avoid their replacement by the opposition. Azzimonti (2011) shows that the larger the conflict among parties (polarization) and the larger are, therefore, the losses of being replaced (as preferred policies will be more divergent), the larger is the overspending to avoid replacement. Therefore, public spending is expected to exhibit a positive relationship with the degree of polarization.

Finally, especially to explain cross-country differences in public spending, the literature has indicated that, for example, electoral rules (Persson et al. 2007), ethnic fragmentation (Alesina et al. 1999, Shelton 2007), and income inequality (Meltzer and Richard 1981, 1983, Shelton 2007) are important factors. We refrain from including them as explanatory variables in this study, as they show only limited time variation and, in our model, are therefore already captured by the country-specific fixed effect and time trends.

\section{Data and empirical model}

\subsection{Data and variables}

The analysed panel comprises annual data (1980-2013) for 21 OECD economies, namely Australia (AUS), Austria (AUT), Belgium (BEL), Canada (CAN), Denmark (DNK), Fin-

\footnotetext{
${ }^{9}$ The effect of elections on the composition of public spending has also been analysed at the regional and local government level, where it is shown that in election years incumbents spend more on 'more visible goods' like infrastructure compared with other spending categories. For a summary of this literature see Drazen and Eslava (2010).
} 
land (FIN), France (FRA), Germany (GER), Greece (GRC), Ireland (IRL), Italy (ITA), Japan (JPN), Luxembourg (LUX), the Netherlands (NLD), New Zealand (NZL), Norway (NOR), Portugal (PRT), Spain (ESP), Sweden (SWE), the United Kingdom (UK), and the United States (US). ${ }^{10}$ Table 1 provides details on variables and data sources.

$\mathrm{PE}$ and SE is per capita public expenditure and public social expenditure, respectively, measured in logarithms of quotes in US dollar and US purchasing power parity implied prices with 2005 as the base year. Before taking the log transformation we determine the difference between total public expenditure and social expenditures. The log of this quantity, public non-social expenditure, is henceforth denoted NSE.

Raw quotes for the determination of SE are from the Social Expenditure Database (SOCX) and comprise all cash expenditures (including lump-sum payments) on old-age pension and other services and payments to elderly people ('old age'), benefits for spouse or dependents of deceased persons ('survivors'), cash payments due to complete or partial inability to participate gainfully in the labour market ('incapacity-related benefits'), all public expenditure on health ('health'), expenditure related to the costs of raising children or supporting other dependants ('family'), all social expenditures (other than education) that aim at the improvement of the beneficiaries' prospect to find gainful employment, or to otherwise increase their earnings capacity ('active labour market programs'), cash expenditure to people compensating for unemployment ('unemployment'), rent subsidies and other benefits to the individual to help with housing costs ('housing'), and payments to people that are not included in the other categories, for example, to immigrants, refugees or indigenous people ('other social policy areas'). ${ }^{11}$ Thus, NSE as its main components covers expenditures on education, transport and communication, defence, subsidies to the industry and the agricultural sector, and government expenditure in general. It turns out that for some countries and time periods annual growth rates for at least one of the three alternative expenditure categories (SE, NSE, PE) exceed 20\% in absolute terms. To guard against potentially adverse effects of outlying observations on OLS/GLS estimation, we removed these observations from the sample. ${ }^{12}$ As a consequence, and owing to nonavailability of a few quotes on PE (JPN (until 1993), NZL (until 1985) and PRT (until 1989)), the panel is unbalanced.

To characterize the long-run trends in $\mathrm{PE}$, we rely on explanatory variables that are common to explain cross-country and time variations of $\mathrm{PE}$ or its components, namely, per capita gross domestic product (GDP), the unemployment rate (UE) and the dependency ratio (DR) (e.g., Hicks and Swank 1992, Sanz and Velazquez 2007, Shelton 2007, Herwartz and Theilen 2014a). GDP is measured in logarithms of quotes in US dollar and US purchasing power parity implied prices with 2005 as the base year. UE is the number of unemployed persons as a ratio of the total labor force. DR is the population share aged less than 15 or older than 65 .

\footnotetext{
${ }^{10}$ The country and sample period selection is due to data availability. Thus, SE data is available in the SOCX data base from 1980. However, for OECD members that joint after this year the data is incomplete and therefore, we have not included these countries in the analysis. Island and Switzerland have not been included because of missing data for some of our variables.

${ }^{11}$ For more details see Adema et al. (2011).

${ }^{12}$ Excessive growth rates of at least one expenditure category show up for AUT/1990, BEL/1990, GER/1990-91, GER/1995-96, DNK/1990, ESP/1982, FIN/1990, GRC/1982-83, GRC/1990, IRL/1985, IRL/2010-11, ITA/1990, JPN/1998, NZL/2010, SWE/1990 and SWE/1995.
} 
Short-run dynamics of PE, SE and NSE are explained by three types of variables: Economic, demographic and political covariates. As economic variables, apart from GDP and UE, we use the volume of trade (TRADE), the current account balance (NX), the general government surplus (SURP), a dummy variable that indicates excessive debt (DEBT90), and a dummy for the period after the financial crisis in 2007 (D07). The variables TRADE and NX are used to account for the degree of openness of the economy. TRADE is the sum of exports and imports, and measures the total volume of trade, while NX is their difference and, therefore, indicates the benefits from trade. Both variables are measured as shares of GDP. Cameron (1978), or more recently, Shelton (2007) argue that trade openness is positively related to government size. This is explained by an increased demand for public insurance against external risks faced by firms and households (Rodrik 1998, Iversen 2001). Herwartz and Theilen (2014a), however, find that increased trade openness and export surpluses go along with less public spending on social issues. This is explained by the fact that with an increased trade dependency and more international competition, governments have intended to attract foreign investments (and to retain domestic investments) by reducing corporate taxation and other tax and social security payments of firms which has created pressures to downsize the public sector (Bénassy-Quéré et al. 2007, Chengrui 2014). Government surplus (SURP) is considered as an important determinant of public spending, since many governments in developed economies have become increasingly indebted over the last three decades. This has imposed constraints on the maintenance and the expansion of public expenditures, as continuous budget deficits and increased accumulated debt have deteriorated the financing conditions on international capital markets (yields of long-term government bonds). Consequently, we expect a positive relationship between SURP, measured in percentage of GDP, and public spending. In the same vein, with DEBT90 we identify particular states of excessive debt. As a benchmark, we consider the $90 \%$ of GDP debt value which has been indicated as a "critical debt level' for economic growth by Reinhard and Rogoff (2010a,b). ${ }^{13}$ Accordingly, $D E B T 90=1$ if the DEBT to GDP ratio is larger than $90 \%$, and DEBT90 = 0 otherwise. A time dummy for the period after 2007 allows for structural shifts in public spending that came along with the great recession starting with the Lehman default in 2008, i.e., the sequel of the financial and sovereign debt crisis.

Regarding the explanatory demographic variables for short-run dynamics of SE and NSE, we use the population share of the young aged under $15(\mathrm{P} 15)$, and the population share of the elderly aged more than 65 (P65) separately, as changes in these variables are expected to have distinguished impacts on SE and NSE. For example, while an increase in P15 should mainly impact on NSE which includes education expenditure, an increase in $\mathrm{P} 65$, in the absence of policy responses, will substantially raise SE, since this public spending category includes pensions and health care expenditures.

While the inclusion of political explanatory variables has already been justified by the discussion in the previous section, here we are more precise on measurement issues. We use government ideology (IDEO), a dummy that indicates election years (ELEC), an indicator for the polarization of the party system (POLA), and the number of government coalition partners (NCP). The variable IDEO is the (unweighted) mean of the ideological position

\footnotetext{
${ }^{13}$ Alternatively, we have considered $80 \%$ and $100 \%$ benchmarks which yields qualitatively identical results.
} 
of parties in government. ${ }^{14}$ Party ideology is measured on a -5 to 5 scale, where positive (negative) values indicate rightist (leftist) ideological positions. The date of elections is measured as in Franzese (2000) as

$$
E L E C=\frac{(M-1)+d / D}{12},
$$

where $M$ and $d$ indicate the month and day of election, respectively, and $D$ is the number of days in the month of election. In years without elections $E L E C=0$. The polarization of the party system with $J$ parties is measured as

$$
P O L A=\sum_{j=1}^{J} \sum_{l=1}^{J} v_{j}^{2} v_{l}\left|I D E O_{j}-I D E O_{l}\right|,
$$

where $v_{j}$ and $v_{l}$ are the shares of seats in parliament of party $j$ and $l$, respectively. ${ }^{15}$

\subsection{A policy augmented error correction model}

To analyse determinants of public expenditures and indirect redistribution we notice that time series of country specific (log) expenditures are likely characterized by stochastic trends, and, moreover that PE might exhibit a stable relation with fundamental determinants in the long run. Given indicative diagnostics for panel integration and cointegration we follow a flexible approach of stacking single equation error correction models (Engle and Granger, 1987). Such an approach is justified, in particular, if the variables contributing to the considered fundamental (or cointegrating) description of PE do not form other linearly independent equilibrium relations. ${ }^{16}$ Under cointegration of integrated variables the error correction model is a suitable representation of the marginal process of adjustments of PE. Apart from considering standard error correction models, and similar to Herwartz and Theilen (2014a), we evaluate specifications augmented with further predetermined or exogenous information.

Let $i, i=1, \ldots, N$, and $t, t=1, \ldots, T$, indicate cross-section members and time instances, respectively. PE is supposed to exhibit a stable equilibrium relation with variables describing long-term inflows and outflows of financial resources at the governmental level. In specific, we assume that, aside from deterministic components, the long-term level of PE is well described by a linear combination of GDP, the unemployment rate (UE) and the dependency ratio (DR). Apart from well established economic determinants of

\footnotetext{
${ }^{14}$ An alternative would be to take a weighted average of the ideological positions of government parties where the weights are based on their share of seats in parliament. However, such a measure has the disadvantage that it does not reflect the real strength of coalition partners because of their veto power. As the budget allocation on major spending categories (which is in the scope of our analysis) is an important aspect of coalition bargaining and formation, we consider an unconditional average to be more adequate for the purposes of this study.

${ }^{15}$ For properties of this polarization index, see Esteban and Ray (1994).

${ }^{16}$ Test results for panel integration and cointegration are discussed later in the Appendix. The longterm relation to describe PE is supposed to link PE, GDP, UE and DR. In economic terms we are not aware of any further equilibrium relationship linking these variables in the long term. Hence, the assumption of a unit cointegrating rank is reasonable.
} 
long-run patterns of PE (GDP, UE, DR), the presumed cointegrating relation includes a linear trend and a dummy variable that takes values of unity for the periods 2008 to 2013. The inclusion of a linear trend supports the discrimination among stochastic and deterministic trends in PE. The dummy variable accounts for potentially adverse effects of the Lehmann default and the ensuing period of financial and sovereign debt turmoil. In light of these considerations, the respective equilibrium error errors read as

$$
e c_{i t}=P E_{i t}-\beta_{i 1} G D P_{i t}-\beta_{i 2} D R_{i t}-\beta_{i 3} U E_{i t}-\beta_{i 4} t-\beta_{i 5} D 07 .
$$

The single equation error correction mechanism for alternative spending categories $\Psi \in$ $\{P E, S E, N S E\}$ reads as

$$
\Delta \Psi_{i t}=\nu_{i}+\delta_{i}+\alpha_{i} e c_{i t-1}+\phi_{i} \Delta \Psi_{i t-1}+\boldsymbol{z}_{i t}^{\prime} \boldsymbol{\gamma}+u_{i t},
$$

where $\Delta$ denotes the first difference operator, e.g., $\Delta P E_{i t}=P E_{i t}-P E_{i t-1}$. In (2), $\nu_{i}$, $\delta_{i}$, and $\phi_{i}$ are fixed effects, linear trend parameters, and autoregressive parameters, respectively. Of particular interest is how political, macroeconomic, fiscal or demographic influences collected in $\boldsymbol{z}_{i t}$ affect the adjustments of expenditure categories at the panel level. The variables entering $\boldsymbol{z}_{i t}$ will be discussed in more detail below. In the spirit of error-correction mechanisms, the model formalizes how log changes of expenditure categories adjust to predetermined information $\left(e c_{i t-1}\right)$ on an eventually over- or undersized public sector. As a particular merit of the dynamic model in (2) it is worthwhile to mention that we (mostly) refrain from imposing poolability restrictions. In particular, dynamic effects (error correction and autoregressive patterns) are most likely to be country specific. As outlined in Pesaran and Smith (1995), falsely imposing cross sectionally uniform parameters in such cases is likely to induce severe estimation biases for all model parameters in $(2)$.

In the case that $S E=P E$, the model in (2) and (1) largely conforms with a standard error correction (cointegration) model except for the fact that the adjustment patterns in (2) allow for impacts of covariates in $\boldsymbol{z}_{i t}$. A common ECM specification obtains if $\boldsymbol{\gamma}=0$. Stability of the system of the nonstationary level variables holds if $-2<\alpha_{i}<0$. Similar to the specification of the long-term relation in (1), a further important characteristic of the model in (2) is that, except for the variables in $\boldsymbol{z}_{i t}$, all parameters are countryspecific. We restrict the imposition of panel homogeneity assumptions on those effects that correspond to the research questions raised in Section 1 (Q1 to Q3). Hence, these questions are subjected to empirical testing in a rather flexible panel model framework. By implication, it is unlikely that the estimated effects of variables in $\boldsymbol{z}_{i t}$ are biased as a consequence of an eventually restrictive ECM panel regression design. ${ }^{17}$

As mentioned before, modelling PE dynamics by means of (2) and (1) fits into common cointegration approaches if $\Psi=P E$. Noticing that public expenditures can be separated into social and 'non-social' expenditures, it is tempting to investigate if these expenditure aggregates contribute proportionally to the equilibrating dynamics of PE. For this purpose, we specify two 'quasi ECMs' where the left-hand side adjustment process

\footnotetext{
${ }^{17}$ Deterministic terms included in (1) and (2) are not jointly identified. We consider general deterministic patterns which can be estimated in two steps (OLS applied to (1) and panel GLS applied to (2)) to filter out 'observable' heterogeneity in a flexible, data driven manner.
} 
$\triangle P E_{i t}$ is replaced either by $\Delta S E_{i t}$ or $\Delta N S E_{i t}$. For both alternative specifications, the right-hand-side model variables are identical to those in (2), except for the specification of autoregressive dynamics. Within the set of explanatory variables in (2), $\Delta P E_{i t-1}$ is replaced either by $\Delta S E_{i t-1}$ or $\Delta N S E_{i t-1}$.

\subsection{Modelling political influence}

The augmentation of the basic error correction mechanism with covariates $\boldsymbol{z}_{i t}$ allows to quantify how short-run adjustments of spending categories respond to exogenous variables that describe the political context in which spending decisions are taken. Political variables included in $\boldsymbol{z}_{i t}$ are the coalition ideology, information on the electoral cycle, the polarization of the party system, and the number of parties that participate in the government coalition. ${ }^{18}$ In addition, it is likely that spending decisions taken by the government respond to macroeconomic, fiscal and demographic developments in their countries. In this respect, it is noticeable that left- and right-wing government might differ in their adoption of policy measures in response to macroeconomic conditions. For instance, after particularly strong accelerations of the unemployment rate, right-wing governments might be more tempted to reduce unemployment benefits than their left-wing counterparts. In addition, policy responses to changes in economic conditions are likely asymmetric. For instance, after particularly strong decelerations of the unemployment rate, one may hardly expect any policy response that manifestos itself in terms of adjustments of public spending. To allow for asymmetric policy responses to changing macroeconomic or demographic performance, we include interaction effects of coalition ideology with extraordinary changes of economic performance or of demographic states. Introducing these interaction variables, let $S \in\{\Delta \mathrm{GDP}, \Delta \mathrm{UE}, \Delta \mathrm{P} 15, \Delta \mathrm{P} 65, \Delta \mathrm{NX}, \Delta \mathrm{TRADE}, \Delta \mathrm{SURP}, \mathrm{EC}\}$, denote a particular performance measure, and $I($.$) an indicator variable. Formalizing$ interaction with coalition ideology, IDEO, we define the following interaction measures

$$
\begin{aligned}
& S_{i t}^{+}=I D E O_{i t}\left(S_{i t-1}-\bar{S}_{i}\right) I\left(S_{i t-1}-\bar{S}_{i}>0\right) \text { and } \\
& S_{i t}^{-}=-I D E O_{i t}\left(S_{i t-1}-\bar{S}_{i}\right) I\left(S_{i t-1}-\bar{S}_{i}<0\right)
\end{aligned}
$$

where $\bar{S}_{i}$ is used to indicate the cross section specific average of the performance indicator $S_{i t}$. According to the definitions in (3), predetermined country-specific and time-specific states $\left(S_{i t-1}\right)$ are contrasted against the unconditional country-specific level in order to extract states that might deserve particular policy reactions. For instance, one might argue that a positive change of the unemployment rate deserves less political attention if this change is close to the country-specific unconditional performance. Moreover, the definition in (3) allows for asymmetry, as we distinguish extraordinarily large and small

\footnotetext{
${ }^{18}$ To test whether changes in government ideology (IDEO) themselves are independent from changes in the economic environment we have performed regressions of the form: $z_{t}=c_{0}+w_{t} c_{1}+u_{t}$, where $u_{t}$ is an error term, $z_{t}=I D E O_{t}-I D E O_{t-1}$ is the change of government ideology in an election year and $w_{t}$ is a (contemporaneous or lagged) indicator of economic performance (growth rates of: GDP, UE, TRADE, NX, SURP). We find that changes in none of our economic indicators are predictors of changes in government ideology (the results are available from the authors). Finally, notice that $76 \%$ of the elections are regular elections such that endogeneity in the timing of elections should be no issue in our data.
} 
realizations of $S_{i t}$ in the construction of interaction variables. The latter are multiplied with minus unity to facilitate the interpretation of this effect, noticing that the interacting variable $I D E O_{i t}$ is centered and, hence, takes positive (right-wing government) and negative values (left-wing government). In addition to these state-specific interaction effects, we further include interactions of coalition ideology with dummy variables (DEBT90, D07) in $\boldsymbol{z}_{i t}$.

\subsection{Estimation}

\subsubsection{Two-step GLS estimation}

We follow a two-step approach for the implementation of ECMs. In the first step, countryspecific long-run relations for PE are determined by means of static OLS regressions. We refrain from documenting single-country estimates or respective inferential diagnostics in light of potential small sample $(T=34)$ biases. Rather, estimation results are provided at the so-called mean group level (Pesaran and Smith 1995). In a second step, residuals from static regressions are used to establish OLS and GLS estimation of the panel of single equation ECMs. ${ }^{19}$

For the second step of the ECM estimation, residual variances in (2) are markedly varying over the cross-section dimension. For instance, modelling adjustment patterns of $\mathrm{PE}$, the smallest residual variance shows up for $i=8$ (FRA). In relative terms, for 11 (16) cross-section members the residual variance is more than 6 (3) times larger than variance estimates for FRA. ${ }^{20}$ For this reason the panel system of ECMs is quantified by means of cross-sectionally weighted least squares regression (GLS). Hence, countryspecific variables enter the analysis after standardization with estimated cross-section specific residual standard deviations. The weights are determined by means of initial OLS estimation and, then, kept fixed for all further steps of estimation.

\subsubsection{General-to-specific model reduction}

The ECM in (2) comprises 84 (cross-section specific) parameters to describe adjustments of PE (or, similarly, SE and NSE) in a flexible manner (fixed effects, time trends, error correction dynamics, autoregressive dynamics). While country-specific parameters guard against adverse effects of overly restricted pooled panel designs on the one hand, such a framework is likely to suffer from an overly generous parameterization in terms of estimation efficiency. To balance these effects (estimation bias under pooling versus estimation inefficiency under excess parameterization), dummy variables quantify effects with reference to the US as a benchmark economy. In a model-reduction procedure, then, deviations from the US benchmark parameters with weakest significance are removed from the model. The sequential model reduction stops once the smallest absolute $t$-ratio attached to deviations from US benchmark parameters is in excess of 1.64. Parameters

\footnotetext{
${ }^{19}$ According to mean group diagnostics the deterministic trend in (1) lacks significance at typical levels. Excluding the linear trend from the long-run relation, or including quadratic trend patterns obtains second-step ECM results and diagnostics which are qualitatively identical to those reported in this study.

${ }^{20}$ Similar relations hold for panel ECM regressions modelling growth rates of SE and NSE.
} 
in $\gamma$ are not subjected to model reduction steps such that the testing of the research questions raised in Section 1 (Q1 to Q3) refers to a rather flexible empirical model. In addition, modelling eventual economic and political impacts on adjustments of expenditure categories in an unrestricted manner is more convenient to enable an overall perspective on marginal contributions of each variable comprised in $\boldsymbol{z}_{i t}$.

\subsubsection{Further comments on estimation}

As argued above, we quantify policy augmented ECMs for $\Delta P E_{i t}, \Delta S E_{i t}$ and $\Delta N S E_{i t}$. To assess if particular covariates impact differently on the latter two growth rates, we quantify a fourth ECM specification which is obtained from stacking the two regression designs for $\triangle \mathrm{SE}$ and $\triangle \mathrm{NSE}$ in an unrestricted form. The stacked model allows a simultaneous GLS assessment of the model parameters, and conveniently provides estimates for the covariance of those parameter estimators that show up in both regression designs $(\hat{\gamma})$. Hence, it is straightforward to determine a significance test on parameter differentials by means of the stacked GLS regression design which will allow us to address research question Q3 raised in the introduction.

Apart from describing the statistical significance of particular effects, we further comment on the capability of single covariates to explain the variation of adjustment patterns of public expenditures. For this purpose let $\boldsymbol{\theta}=\left(\boldsymbol{\nu}^{\prime}, \boldsymbol{\delta}^{\prime}, \boldsymbol{\alpha}^{\prime}, \boldsymbol{\phi}^{\prime}, \boldsymbol{\gamma}^{\prime}\right)^{\prime}$ denote a $K$-dimensional parameter vector comprising all model parameters that survived the model reduction steps. Further, let $\boldsymbol{y}$ and $X$, respectively, denote the vector of dependent observations and the matrix of explanatory variables, $x_{i t k}, k=1, \ldots, K$. To quantify variable-specific contributions to model accuracy, we employ the following descriptive measure

$$
\bar{R}_{k}^{2}=100 \frac{R_{k}^{2}}{\sum_{k=1}^{K} R_{k}^{2}},
$$

where $R_{k}^{2}$ is the partial degree of explanation offered by variable $x_{i t k}$. To facilitate the interpretation of $\bar{R}_{k}^{2}$, the underlying partial degrees of explanation $\left(R_{k}^{2}\right)$ are determined for the raw data, i.e., log differences of expenditure categories. To fully assess the explanatory content of a particular covariate, statistics $\bar{R}_{k}^{2}$ should be evaluated jointly with the overall degree of explanation achieved by a particular model.

\subsection{Data analysis and first empirical results}

After model definition and the introduction of the considered variables the following analysis is thought to assess in quantitative terms the characteristics of the data, and to justify the adopted (policy-augmented) panel error correction model framework. For this purpose, i) we provide descriptive statistics of the panel data and ii) compare diagnostic outcomes for pure ECM variants with counterparts obtained in the framework of the policy-augmented model. For the discussion of empirical results we refer to the $5 \%$ nominal significance level if not stated otherwise. As further important requirements for the error correction (cointegration) model, diagnostic evidence on nonstationarity and cointegration and an assessment of the mean group relation among PE and its long-term determinants are provided in the Appendix. 


\subsubsection{Descriptive statistics}

Table 2 documents descriptive statistics, mostly for both level measures and first differences. The average annual growth rate of real GDP amounts to $1.6 \%$ which is very close to the mean growth rate of public expenditures (1.7\%). Distinguishing unconditional growth rates for the two disjoint expenditure categories SE and NSE, the former (latter) are markedly in excess (below) average GDP growth. On average, NZL and LUX have seen the smallest and largest growth rates of public expenditures, respectively. While GRC shows the weakest growth of real GDP on average $(0.5 \%)$, it is also characterized by highest average growth rates of 'non-social' expenditure categories $(2.9 \%)$. With respect to demographic trends the descriptive statistics confirm that all considered OECD economies are ageing, since mean changes of the share of the elderly (the young) generation are positive (negative) for all economies. On average, the population share of the elderly has annually increased by 0.148 percentage points, while the share of the young population has annually decreased by -0.178 percentage points. At the side of political variables, the overall average of coalition ideology is close to zero (0.5). On average, the governments of SWE and JPN have been most leftist (-0.41) and most rightist (2.3), respectively. The data show sizeable variations in both directions, between variation and within variation. Not surprisingly, for economic data the ratio of between versus within variation is markedly larger for level data than for quotes on first differences.

\subsubsection{Country-specific growth patterns of expenditure categories}

Focussing on the marginal explanatory content of macroeconomic and political variables, Table 3 provides estimation and diagnostic results for error correction type models including and excluding the exogenous variables collected in $\boldsymbol{z}_{i t}$. In addition, the estimation results are thought to underpin the prevalence of error correction and autoregressive dynamics in the adjustments of expenditure categories. Table 3 also documents benchmark (US) estimation results for the deterministic terms $\left(\hat{\nu}_{U S}, \hat{\delta}_{U S}\right)$, and error correction and autoregressive dynamics $\left(\hat{\alpha}_{U S}, \hat{\phi}_{U S}\right)$.

Contrasting the restricted $(\boldsymbol{\gamma}=0)$ and the unrestricted ECM shows that the model augmentation with exogenous socio-economic and political variables enhances the models' explanatory content for each expenditure category. For adjustment patterns of PE, the $R^{2}$ of the restricted model $(\gamma=0)$ is improved by about $40 \%$ (10 percentage points). With regard to adjustment patterns of SE and NSE, the improvements in the degree of explanation are even larger, noticing that the degrees of explanation are almost twice as large for the policy augmented models. ${ }^{21}$ The fact that, in comparison with PE, the gain in model accuracy is larger for both subcategories of expenditures might be seen as a first hint on heterogeneity of the adjustment patterns of SE and NSE. The likelihood of cross model heterogeneity (SE versus NSE) is further underpinned by significance of parameter differentials that can be diagnosed for the fixed effects US benchmark parameter $\left(\hat{\nu}_{U S}\right)$. In the US, the unconditional growth of social expenditures has been significantly in excess of the respective quantity of NSE (see parameter differentials listed in column ' $\Delta \mathrm{SE}-\Delta \mathrm{NSE}$ '

\footnotetext{
${ }^{21}$ While the panel ECMs are estimated with cross-sectionally weighted OLS (GLS) the documented degrees of explanation refer to original (non standardized) growth rates of PE, SE or NSE.
} 
in Table 3). Error correction dynamics are also markedly different, with SE showing a more sluggish adjustment to violations of the long-run equilibrium among $\mathrm{PE}$ and its longterm determinants (GDP, UE, DR and deterministic terms). This differential, however, lacks significance in the more general augmented ECM $(\boldsymbol{\gamma} \neq 0)$. In summary, we can conclude that annual growth patterns of SE and NSE are heterogeneous.

The case where the left-hand-side variable of the model in (2) is $\Delta P E_{i t}$ and $\boldsymbol{z}_{i t}$ is excluded from the model $(\boldsymbol{\gamma}=0)$, coincides with a standard error correction (cointegration) model. As shown for this model in the upper panel of Table 3, the error correction dynamics for the US benchmark are significant at any level noticing that the $t$-statistic of the EC coefficient is about -3.8. Hence, the two-step GLS model confirms the evidence from preliminary cointegration tests (see the Appendix). Interestingly, both subcategories of $\mathrm{PE}$ contribute significantly to error correction dynamics if the restriction $\gamma=0$ is imposed. Augmenting the ECM with socio-economic and political variables $\boldsymbol{z}_{i t}(\boldsymbol{\gamma} \neq 0)$, the response of SE and NSE growth to violations of the equilibrium among PE and its long-term determinants remains negative but becomes insignificant. From more detailed estimation results shown in Table 4, however, we can diagnose significant EC dynamics for SE growth for five economies (DNK, FIN, NOR, LUX and PRT). The EC coefficient estimate for FRA, i.e., its deviation from the US benchmark, is significantly positive. ${ }^{22}$ Similarly, for NSE growth four economies show significant adjustments in response to PE deviating from its long-term equilibrium (JPY, NOR, LUX, PRT). The EC coefficient estimated for BEL, i.e., its deviation from the US benchmark, is significantly positive. As a further hint at significant error correction dynamics, it is worth noting that deviations from country-specific PE equilibria account for $23.4 \%$ (PE growth) and about $10 \%$ (SE and NSE growth) of the overall explanatory content achieved by means of the policy augmented ECM specifications.

\section{The determinants of redistribution through social spending}

In this section we comment on the impact of socio-economic and political variables on the short-run dynamics of PE, SE, and NSE, respectively. This means that we focus on the determinants of the second step of the budgeting process, i.e., the determinants of its distribution on different spending categories. The estimation results are displayed in Table 5 and Table 6. In Section 4.1, we comment on the role of macroeconomic, fiscal and demographic variables in adjusting public expenditures. In Section 4.2, we assess the political determinants of redistributive spending which will allow us to respond to our first question (Q1). In Section 4.3, we analyse whether governments respond differently to macroeconomic, fiscal and demographic changes which allows us to come to our second research question (Q2). Finally, in Section 4.4 and Section 4.5 we address the redistributive effects of ideological government positions raised in the third question

\footnotetext{
${ }^{22} \mathrm{As}$ a result of the model reduction steps numerous deviations from US benchmark estimates are insignificant. Testing joint insignificance of the imposed restrictions is supportive for the model reduction. Irrespective of modelling of PE, SE or NSE growth, $p$-values of F-tests are in excess of 0.9.
} 
(Q3). In commenting the significance of the results, again, if not otherwise mentioned, significance refers at least to the 5 percent level.

\subsection{The role of macroeconomic and fiscal performance and de- mography in adjusting public expenditures}

For the three complementary model specifications Table 5 documents parameter estimates and diagnostics assessing the impact of macroeconomic and fiscal conditions, as well as demographic variables on growth patterns of the distinguished expenditure categories. Noticing that the empirical models also comprise interaction effects of state variables and the ideological position of the government, the estimation results in the upper panel of Table 5 are representative for a 'central' ideological position $\left(I D E O_{i t}=0\right)$. Hence, to assess the overall impact of macroeconomic and fiscal conditions, as well as demographic variables on growth of public spending, it will be important later to take eventual interaction effects with the ideology measure into account. ${ }^{23}$

For several variables included in $\boldsymbol{z}_{i t}$ we find marginal impacts on short-run adjustment patterns of PE that accord with a-priori economic reasoning under the condition of a 'central', ideological position of the government. As macroeconomic performance indicators, GDP growth and changes of the unemployment rate invoke upward adjustments of PE which, however, lack significance. Ceteris paribus, lagged upward adjustments of external positions $(\Delta N X)$ go along with insignificantly reduced growth of PE. Indicating the importance of demographic patterns, lagged positive changes of the population shares of both the young and the elderly induce significant upward adjustments of public spending. Therefore, demographic changes are not only important in explaining long-run trends but also short-run adjustments of public spending. The estimated effects of budget surpluses and states of excessive debt (exceeding $90 \%$ of GDP) on growth of PE are both significant. As could be expected, PE growth shrinks (increases) in response to lagged deficits (surpluses). States of particularly high government debt invoke downward adjustments of PE. Interestingly, significance of the parameter attached to the dummy variable $D 07$ shows that growth rates of PE have adjusted upwards in the context of the (ongoing) financial and government debt crises. In conjunction with results describing the long-run (level) effect of this variable (see the Appendix), this indicates that fiscal measures undertaken to stabilize the financial sector and to stimulate the economy in light of the recent massive economic distortions have commanded repeated upward expenditure adjustments.

Apart from parameter estimates and indicators of statistical significance, the results in Table 5 are also informative on the 'economic' significance of the employed covariates, i.e., their marginal contribution to the overall explanatory content of the model. As it turns out, among the variables in $\boldsymbol{z}_{i t}$ that contribute most to the sum over variable specific partial $R^{2}$ statistics are lags of budget surplus (5.66\%), the crisis indicator $(2.61 \%)$, and excess levels of public debt $(2.29 \%)$.

Separating expenditure categories SE and NSE, shows that both categories respond to all conditioning variables in $\boldsymbol{z}_{i t}$ in a comparable manner (and magnitude) as discussed for

\footnotetext{
${ }^{23}$ Estimating the panel models without including interaction effects in $\boldsymbol{z}_{i t}$ obtains results that are quantitatively similar to those reported in the upper panel of Table 5.
} 
PE growth. Three out of nine marginal effects estimated for growth in SE and NSE differ, however, significantly. Firstly, ceteris paribus, social expenditure increases significantly after an increase of the population share of the elderly, while the respective growth rate for NSE is insignificantly negative. The stronger impact of changes in P65 on SE reflects that particular expenditure types included in SE (e.g., 'health care' or 'old age') are more important for ageing economies. Secondly, distinguished states of positive GDP growth rates and increases of unemployment invoke a significant (insignificant) positive response of growth in NSE (SE). Thirdly, during the financial and sovereign debt crisis (D07) growth of NSE is significantly in excess of SE growth. This result indicates that in the sequel of economic downturn, the stabilization of the financial sector has attracted more financial means from the NSE than the SE spending category.

\subsection{Political determinants of redistributive spending}

We respond to the first of our research questions (Q1) by means of analysing the marginal impacts of political variables on adjustments of public expenditure categories. Respective regression results are documented in the lower panel of Table 5. On average, irrespective of the considered spending category, we find that the level of polarization of the political party system, and the ideological position of the government do not exert marginal influences on growth of public spending. Related cross-section studies focusing on developed economies also find that legislative polarization has no statistically significant effect on fiscal outcomes (Volkerink and De Hann 2001, Elgie and McMenamin 2008). Furthermore, Persson et al. (2007) have shown that the polarization of the party system is closely related to electoral rules which are captured in our study by country-specific fixed effects. Therefore, cross-country differences in the polarization of the party system are not fully captured by POLA which also explains insignificance of this variable. For a full assessment of the impact of ideological positions on government spending, the coefficient estimate in the lower panel of Table 5 is of limited value, however, given that the empirical models comprise interactions among state variables and ideology. Hence, the effect of ideology on public spending patterns will be further discussed below.

With regard to growth of total public spending, electoral cycles are prevalent with $10 \%$ significance. Before elections, public expenditures see, on average, additional growth of $0.6 \%$. As it turns out, electoral cycles have more and significant explanatory content for SE growth $\left(1.42 \%\right.$ of aggregated partial $\left.R^{2}\right)$ in comparison with NSE growth $(0.26 \%)$. Hence, the effect of electoral cycles is redistributive, and might reflect that income redistribution is an important issue in political campaigns during election periods.

Finally, the influence of the number of government coalition partners on PE growth is significantly negative. While the explanatory content $(0.67 \%)$ of this effect is rather small, it is noteworthy that it is well in line with theoretical arguments put forth by Tsebilis (1995, 2002). Ceteris paribus, the number of veto players (coalition partners) exerts a stabilizing, i.e. negative, effect on the PE growth. For both considered categories of public spending, however, the significance of veto-player effects vanishes. 


\subsection{Party response to macroeconomic, fiscal and demographic changes}

The preceding discussion has highlighted that macroeconomic, fiscal and demographic patterns are important to explain transitory adjustments of public budgets. In addition, the ideological position of the government appeared inessential in shaping growth rates of public expenditure and its categories. In considering interaction effects, henceforth, we analyse if left-wing or right-wing governments differ in their policy response to macroeconomic, fiscal and demographic changes. Describing patterns of PE growth, the left-hand-side panel of Table 6 documents estimated effects of governmental ideology interacted with socio-economic and political variables.

As indicated by the significance of numerous parameter estimates, the ideological position of coalitions is of core importance to understand policy responses to macroeconomic, fiscal and demographic changes. Moreover, the asymmetric policy response that is implied by the specification of interaction variables, is fully supported by the data. For instance, above (below) average changes of GDP, UE and P65 invoke significantly (insignificantly) distinct policy responses of left-wing and right-wing governments.

We find that left-wing governments raise PE more than their right-wing counterparts after periods of above average changes of GDP, UE or P65. Or, put differently, under favourable economic conditions right-wing governments reduce public budgets more rigorously than their left-wing counterparts. This indicates that, in recent periods, ideologically motivated adjustments in the size of the public sector (e.g., Cameron 1978, Alesina 1987, Hibbs 1977, Cusack 1997) depend on the underlying socio-economic conditions. The parameter estimates for the external position (interacted with ideology) imply that left-wing (right-wing) governments show highest (smallest) growth rates of public expenditures in situations where import and export changes offset each other. To explain this finding from the perspective of right-wing governments, we have that both excess export growth and excess import growth invoke upward adjustment of public expenditures. These implications might be rationalized by presuming that right-wing governments either condition the growth of the public sector on successful economic performance on international markets (in case of an improvement of the current account), or on perceived needs to improve the competitiveness of domestic firms (in case of a deterioration of the current account).

Interacting governmental ideology with fiscal variables or the indicators of the financial crises (SURP, DEBT90, D07) lacks distinctive policy responses on growth of PE. Given the result for governments with a 'central' ideological position $\left(I D E O_{i t}=0\right)$ described before, insignificance of interaction patterns suggests that, in periods of fiscal stress or debt crises, the scope of ideologically motivated spending programs or budget consolidation is limited.

Positive deviations from the equilibrium between PE and its long-term determinants might be seen to indicate an oversized public sector. In the framework of the adopted ECM such deviations are expected to invoke stabilizing, i.e., downward adjustments of public expenditures. Interacting lagged periods of overspending with ideological positions, shows that policy responses of right-wing governments spur the adjustment towards equilibrium significantly. Remarkably, among all interaction terms this effect shows highest 
marginal explanatory content $\left(2.14 \%\right.$ of the aggregated sum of partial $\left.R^{2}\right)$. Moreover, it is worthwhile noticing that a public sector sized below its perceived equilibrium does not invoke ideologically distinguished policy responses.

Finally, the interaction of ideological positions with other political variables is found to be positively significant for polarization (with $10 \%$ significance), negatively significant for election years and insignificant for the number of partners in coalition. All these effects, however, contribute only marginally to the explanation of PE growth (in total $0.68 \%$ of aggregated sum of the partial $R^{2}$ ).

\subsection{Redistributive effects of ideological government positions}

The preceding discussions allow, in particular, two conclusions with regard to the effect of ideological government positions. Firstly, coalition ideology lacks a direct impact on short-term adjustments of PE and its categories (SE and NSE). Secondly, the ideological position of coalitions is important to explain growth patterns of public expenditure under varying macroeconomic, fiscal or demographic conditions. From the latter findings it is of immediate interest to analyse if redistributive effects of ideological government positions, i.e., distinguished influences of ideology on SE and NSE growth, are also channelled through varying macroeconomic, fiscal or demographic situations. Before we turn to this analysis, a few significant ideological influences on the growth of SE are worthwhile mentioning (see the second block of results in Table 6). In comparison with their rightwing counterparts, left-wing governments are more reluctant to reduce SE in the sequel of above average changes of unemployment, and after states of public debt in excess of $90 \%$ of GDP. On the contrary, situations of below average growth of GDP and of the share of the elderly population invoke lower SE reductions under right-wing than under leftwing governments. Interestingly, we find that the above diagnosed ideologically motivated electoral cycle effect for public spending, in case of SE, is more pronounced for left-wing than for right-wing parties. This indicates that parties do not arbitrarily increase public spending in election years, but focus on those spending categories that are closer to their partisan interests. Finally, it turns out that multipartner right-wing coalitions show higher SE growth than their left-wing counterparts.

Turning to the discussion of distinguished influences of ideology, the rightmost column of Table 6 provides parameter differentials and respective $t$-ratios for interaction effects quantified for SE versus NSE growth. Out of 21 parameter differentials six are nonzero (three with $5 \%$ and three with $10 \%$ significance), indicating redistributive effects of government ideology.

In the first place, above average changes of GDP growth invoke distinguished policy responses from left-wing and right-wing governments on SE and NSE growth. While above average GDP growth is not important for adjustments of SE, this effect is channelled through distinguished government responses of NSE growth to GDP growth. Estimation results imply that, as opposed to their left-wing counterparts, right-wing governments mute NSE growth after favourable economic performance.

Secondly, after large reductions of the young generation's share in total population $\left(\triangle P 15^{-}\right)$left-wing governments tend to increase social spending, while right-wing governments foster expenditures in the categories of NSE. To explain this result, it appears 
that coping with such unfavourable demographic trends, left-wing governments might opt for more spending in, e.g., family programs, while their right-wing counterparts might put more focus on improved education. While the difference between estimated parameters of interaction effects is significant in statistical terms, it is important to notice that the described effect has only limited content to explain the growth of expenditure categories (respective contributions to the overall sum of partial degrees of explanation are at most $0.22 \%)$.

In the third place, while coping with large upward changes of the population share of the elderly lacks redistributive characteristics, below average changes of this population share invoke ideology dependent adjustments of SE versus NSE growth. As can be expected, this effect comes mainly from distinguished government responses to such changes in SE, where spending programs targeted to the elderly are particularly important.

Fourthly, responding to changes of the external position the ideological position of the government matters for adjustments of SE and NSE spending. Our estimation results indicate that after a deterioration of the current account balance, right-wing governments react with an increased spending in NSE, while muting the growth of SE. Hence, the policy reaction might be explained by the notion that marked negative changes of the external position are perceived as an indication of weak competitiveness of domestic firms on international markets. To this perception right-wing governments react more strongly than their left-wing counterparts, to foster competitiveness on international markets. Apparently, policy instruments that are in line with this objective (e.g., improvements of infrastructure, enhancement of productivity by means of better education) are among NSE spending categories. Similarly, the muting of SE might contribute to an enhancement of international competitiveness (e.g., reductions of contributions of firms to social security systems).

In the fifth place, we find that the above mentioned strong response of right-wing governments to an oversized public sector (i.e., large positive deviations of $\mathrm{PE}$ from its long-term determinants) is channelled through adjustments of NSE growth. To explain this result, we notice that budget cuts are likely less subjected to social conflict, if respective policy measures fall into NSE instead of SE spending categories.

Finally, the above mentioned positive effect of polarization on the growth of public spending under right-wing governments is mainly due to policy measures financed by means of NSE categories. This is not surprising as, on the one hand, these spending categories are more heterogeneous and, therefore, spending on them allows a better matching when voter preferences (and party systems) are highly polarized, and, on the other hand, NSE categories are closer to the core interests of right-wing partisans.

\subsection{A global perspective on the redistribute effects of ideological government positions}

The preceding discussions have unravelled important marginal effects of ideological government positions on distinguished spending in SE and NSE categories. While we referred to some particular economic and demographic scenarios to reflect favourable or unfavourable macroeconomic and demographic performance, yet, a joint assessment of the typically contemporaneous developments is warranted. To provide a global assess- 
ment on redistribute effects of ideological government positions, we a-priori consider the following states to (jointly) indicate favourable socio-economic performance: $\triangle \mathrm{GDP}^{+}$, $\Delta \mathrm{UE}^{-}, \Delta \mathrm{P} 15^{+}, \Delta \mathrm{P} 65^{-}, \Delta \mathrm{NX}^{+}, \Delta \mathrm{TRADE}^{+}$and $\mathrm{SURP}^{+}$. At the opposite, $\Delta \mathrm{GDP}^{-}$, $\Delta \mathrm{UE}^{+}, \Delta \mathrm{P} 15^{-}, \Delta \mathrm{P} 65^{+}, \Delta \mathrm{NX}^{-}, \Delta \mathrm{TRADE}^{-}, \mathrm{SURP}^{-}$and DEBT90 are (jointly) considered unfavourable. Moreover, we consider positive $\left(\mathrm{EC}^{+}\right)$and negative $\left(\mathrm{EC}^{-}\right)$violations of the equilibrium among $\mathrm{PE}$ and its long-run determinants. Noticing that the former might signal an oversized public sector, $\mathrm{EC}^{+}$is classified among the unfavourable performance criteria. Hence, a negative impact direction (see, e.g., the effect of $\mathrm{EC}^{+}$on $\Delta$ SE documented in Table 7) implies that in comparison with left-wing coalitions, rightwing coalitions reduce public spending in a way that the adjustment towards the long-run equilibrium is faster. ${ }^{24}$ With these distinctions at hand, Table 7 documents the state dependent directions of expenditure growth triggered by the ideological position of the government (coalition).

Interestingly, once it is accounted for states of favourable and unfavourable conditions, the documented effects of government ideology appear to point into a dominating direction. Although not all single effects are significant (see Table 6), it is tempting to assess their joint contribution to the explanatory content of the policy augmented ECM. To assess 'joint' significance, the marginal explanatory contents of single effects are aggregated according to impact directions and shown in the bottom lines of Table 7.

Conditional on favourable socio-economic performance, the directional patterns displayed in Table 7 exhibit a striking asymmetry. By implication, favourable performance can be considered a prerequisite for right-wing governments to raise SE. In the same time, these governments tend to reduce, ceteris paribus, spending in NSE categories in response to favourable socio-economic performance. In terms of explanatory content, it turns out that the second effect if of particular importance. In summary, under favourable economic conditions, right-wing policies have more progressively redistributive effects than left-wing policies. Under unfavourable states of socio-economic performance, right-wing coalitions are more willing to reduce SE, while in the same time NSE categories receive more attention in comparison with their left-wing counterparts. Both effects share a comparable overall contribution to the explanatory content of the empirical models. Moreover, in comparison with conditioning on favourable socio-economic conditions, unfavourable conditions offer markedly more explanatory content of the empirical models. In summary, under unfavourable economic conditions left-wing policies act more progressively redistributive than right-wing policies. Comparing the opposing effects diagnosed after conditioning on socio-economic performance, the progressively redistributive effect of leftwing policies (under unfavourable socio-economic performance) is diagnosed stronger than its right-wing policy induced counterpart (favourable socio-economic performance).

\section{Conclusions}

Ongoing processes of liberalization of international goods and capital markets, typically summarized under the notion of globalization, affect the opportunities to redistribute

\footnotetext{
${ }^{24}$ To facilitate the model interpretation the effect of EC is multiplied by minus unity, since the EC parameter $\alpha_{i}$ in (2) is required to be negative for model stability.
} 
income and welfare according to the ideological positions of the political parties in government. In the last decades, taxation as a classical means of redistribution has lost effectiveness. Against this background, public spending has come in the focus of political parties as a means to realize distributional outcomes which are in line with their partisan interests. For a panel of 21 OECD economies and the time period 1980-2013 we adopt flexible panel error correction models to analyse if party ideology contributes actively to the sizing of the public sector and, more importantly, if party ideology shapes redistributive outcomes that result from the distinction of 'social' versus 'non-social' expenditures.

Apart from diagnosing significant electoral cycles of public spending, our results largely confirm recent evidence that - unconditionally - ideological positions of political parties hardly explain the growth of the public sector. In light of particular demographic trends, and stances of fiscal or macroeconomic performance, however, the expansion or consolidation of the public sector reflects ideological positions. In addition, as left-wing and rightwing governments differ in their prioritization of expansion versus consolidation of 'social' and 'non-social' expenditure categories, public spending turns out to be redistributive. Spending patterns of both left-wing and right-wing governments are progressively redistributive. While left-wing governments act redistributive in response to disadvantageous demographic trends, and unfavourable stances of fiscal or macroeconomic performance, right-wing governments do so in response to more favourable conditions.

With regard to macroeconomic and fiscal conditions, the diagnosed response patterns could imply a sequel of regressive and progressive distribution outcomes over the business cycle. Jointly with states of welfare distribution the states of the business cycle are important determinants of electoral outcomes. As an issue for future research it is tempting to address if ideology matters for distributional outcomes in the long term. For such an analysis, the joint endogeneity of political and business cycles deserves particular consideration. Spatial disaggregation opens a further direction for future research. In such a framework, it will be of interest in how far the interplay of central state government ideology with patterns of local competition further bound the scope of ideologically motivated redistributive spending at the level of districts or federal states. Finally, refining public spending categories in the vein of Shelton (2007) and Brender and Drazen (2013) in the framework of our model might allow to identify further government ideology motivated differences in public spending categories.

\section{References}

Abbas SMA., Belhocine N., ElGanainy AA., Horton MA. 2010. A historical public debt database. IMF Working Paper WP/10/245. Washington, DC.

Adema W., Fron P., Ladaique M. 2011. Is the European Welfare State Really More Expensive?: Indicators on Social Spending, 1980-2012; and a Manual to the OECD Social Expenditure Database (SOCX). OECD Social, Employment and Migration Working Papers, No. 124. Paris: OECD.

Afonso A., Schuknecht L., Tanzi V. 2010. Income distribution determinants and public spending efficiency. Journal of Economic Inequality 8: 367-389. 
Alesina A. 1987. Macroeconomic policy in a two-party system as a repeated game. Quarterly journal of Economics 102: 651-678.

Alesina A. Baqir R., Easterly W. 1999. Public goods and ethnic divisions. Quarterly Journal of Economics 114: 1214-1284.

Alesina A., Roubini N., Cohen GD. 1997. Political Cycles and the Macroeconomy. Cambridge: The MIT Press.

Azzimonti M. 2011. Barriers to investment in polarized societies. American Economic Review 101: 2182-2204.

Bénassy-Quéré A., Gobalraja N., Trannoy A. 2007. Tax and public input competition. Economic Policy 50: 385-430.

Benoit K., Laver M. 2006. Party Policy in Modern Democracies. New York: Routledge.

Bowler S., Donovan T., Karp JA. 2006. Why politicians like electoral institutions: selfinterest, values, or ideology? The Journal of Politics 68: 434-446.

Bradley D., Huber E., Moller S., Nielsen F., Stephens JD. 2003. Distribution and redistribution in postindustrial democracies. World Politics 55: 193-228.

Bräuninger T. 2005. A partisan model of government expenditure. Public Choice 125: 409-429.

Breitung, J. and S. Das. 2005. Panel unit root tests under cross sectional dependence, Statistica Neerlandica 59: 414-433.

Brender A., Drazen A. 2005. Political budget cycles in new versus established democracies. Journal of Monetary Economics 52: 1271-1295.

Brender A., Drazen A. 2013. Elections, leaders, and the composition of government spending. Journal of Public Economics 97: 18-31.

Cameron DR. 1978. The expansion of the public economy: a comparative analysis. The American Political Science Review 72: 1243-1261.

Chengrui X. 2014. The international corporate competition: how do countries interact with each other. PhD Dissertation. University of Oklahoma.

Cusack TR. 1997. Partisan politics and public finance: changes in public spending in the industrialized democracies, 1955-1989. Public Choice 91: 375-395.

Cusack TR., Beramendi P. 2006. Taxing Work. European Journal of Political Research 45: $43-73$.

De Donder P., Hindriks J. 2007. Equilibrium social insurance with policy-motivated parties. European Journal of Political Economy 23: 624-640. 
Demetrescu M, Hanck C. 2012. A simple nonstationary-volatility robust panel unit root test. Economics Letters 117: 10-13.

Döring H., Manow P. 2011. ParlGov Database. Retrieved March 2, 2013. Accessible at: http://parlgov.org/stable/index.html

Drazen A., Eslava M. 2010. Electoral manipulation via voter-friendly spending: theory and evidence. Journal of Development Economics 92: 39-52.

Dreher A., Sturm J-E., Ursprung HW. 2008. The impact of globalization on the composition of government expenditure: evidence from panel data. Public Choice 134: 263-292.

Engle RF., Granger CWJ. 1987. Cointegration and error correction: Representation, estimation and testing. Econometrica 55: 251-276.

Elgie R., McMenamin I. 2008. Political fragmentation, fiscal deficits and political institutionalism. Public Choice 136: 255-267.

Esteban J-M., Ray D. 1994. On the measurement of polarization. Econometrica 62: 819-851.

EUROSTAT. 2015. Eurostat Database. Retrieved March 25, 2015. Accessible at: http://ec.europa.eu/eurostat/data/database

EWI. 2015. Recent public expenditure items worldwide 1980-2013. Retrieved March 19, 2015. Accessible at: http://www.economicswebinstitute.org/ecdata.htm

Folke O. 2014. Shades of brown and green: party effects in proportional election systems. Journal of the European Economic Association 12: 1361-1395.

Franzese R. 2000. Electoral and partisan manipulation of public debt in developed democracies, 1956-1990. In: Strauch R., von Hagen J. (Eds.). Institutions, Politics and Fiscal Policy. Dordrecht: Kluwer Academic Press.

Galli E. 2002. Tax progressivity and economic and political determinants: an empirical analysis for the OECD countries. Pavia: University of Pavia.

Gemmell N., Kneller R., Sanz I. 2008. Foreign investment, international trade and the size and structure of public expenditures. European Journal of Political Economy 24: $151-71$.

Gerber ER., Hopkins DJ. 2011. When mayors matter: estimating the impact of mayoral partisanship on city policy. American Journal of Political Science 55: 326-339.

Herwartz H., Siedenburg F. 2008. Homogeneous panel unit root tests under cross sectional dependence: Finite sample modifications and the wild bootstrap. Computational Statistics and Data Analysis 53: 137-50. 
Herwartz H., Theilen B. 2014a. Partisan influence on social spending under market integration, fiscal pressure and institutional change. European Journal of Political Economy 34: 409-424.

Herwartz H., Theilen B. 2014b. Health care and ideology: A reconsideration of political determinants of public healthcare funding in the OECD. Health Economics, 23: 225-240.

Hibbs Jr. DA. 1977. Political parties and macroeconomic policy. American Political Science Review 71: 1467-1487.

Hibbs Jr. DA. 1987. The Political Economy of Industrial Democracies. Cambridge: Harvard University Press.

Hicks AM., Swank DH. 1992. Politics, institutions, and welfare spending in industrialized democracies, 1960-1982. American Political Science Review 86: 658-74.

IMF. 2012. Historical Public Debt Database. Retrieved March 14, 2013. Accessible at: http://www.imf.org/external/pubs/cat/longres.cfm?sk=24332.0

Iversen T. 2001. The dynamics of the welfare state expansion: trade openness, deindustrialization, and partisan politics. In: Piersson P. (Ed.). The New Politics of the Welfare State (pp. 45-79). Oxford: Oxford University Press.

Jensen C. 2011. Capitalist systems, de-industrialization, and the politics of public education. Comparative Political Studies 44: 412-435.

Katsimi M., Sarantidis V. 2012. Do elections affect the composition of fiscal policy in developed, established democracies? Public Choice 151: 325-362.

Kittel B., Obinger H. 2003. Political parties, institutions, and the dynamics of social expenditure in times of austerity. Journal of European Public Policy 10: 20-45.

Lee DS., Moretti E., Butler M. 2004. Do voters affect or elect policies? Evidence from the U.S. House. Quarterly Journal of Economics 199: 807-859.

Levin A., Lin CF., Chu CJ. 2002. Unit root tests in panel data: asymptotic and finitesample properties. Journal of Econometrics 108: 1-24.

Meltzer A., Richard S. 1981. A rational theory of the size of government. Journal of Political Economy 89: 914-27.

Meltzer A., Richard S. 1983. Tests of a rational theory of the size of government. Public Choice 41: 403-418.

Nordhaus WD. 1975. The political business cycle. Review of Economic Studies 42: 169-90.

OECD. 2008. Growing unequal? Income distribution and poverty in OECD countries. Paris: OECD. 
OECD. 2011. Divided we stand: Why inequality keeps rising. Paris: OECD.

OECD. 2015a. Health Database. Retrieved April 7, 2015. Accessible at: http://stats.oecd. org/Index.aspx?DatasetCode=HEALTH_STAT

OECD. 2015b. The Social Expenditure Database. Retrieved April 2, 2015. Accessible at: http://stats.oecd.org/viewhtml.aspx?datasetcode=SOCX_AGG\&lang=en

OECD. 2015c. Main Economic Indicators Database. Retrieved March 19, 2015. Accessible at: http://stats.oecd.org/index.aspx?DatasetCode=SNA_TABLE12

Perroti R., Kontopoulos Y. 2002. Fragmented fiscal policy. Journal of Public Economics 86: 191-222.

Persson T., Roland, G. Tabellini G. 2007. Electoral rules and government spending in parliamentary democracies. Quarterly Journal of Political Science 2: 155-188.

Persson T., Tabellini G. 1999. The size and scope of government: comparative government with rational politicians. European Economic review 43: 699-735.

Persson T., Tabellini G. 2000. Political Economics. Explaining Economic Policy. Cambridge: The MIT Press.

Pesaran H., Smith R. 1995. Estimating long run relations from dynamic heterogeneous panels. Journal of Econometrics 68: 79-113.

Peter KS., Buttrick S., Duncan D. 2010. Global reform of personal income taxation, 1981-2005: evidence from 189 countries. National Tax Journal 63: 447-478.

Petterson-Lidbom P. 2008. Do parties matter for economic outcomes? A regression discontinuity approach. Journal of the European Economic Association 6: 10371056.

Pickering A., Rockey J. 2011. Ideology and the growth of government. The Review of Economics and Statistics 93: 907-919.

Phillips PCB., Moon HR. 1999. Linear regression limit theory for nonstationary panel data. Econometrica 67: 1057-1011.

Potrafke N. 2009. Did globalization restrict partisan politics? An empirical evaluation of social expenditure in a panel of OECD countries. Public Choice 140: 105-124.

Potrafke N. 2010. The growth of public health expenditure in OECD countries: do government ideology and electoral motives matter? Journal of Health Economics 29: $797-810$.

Potrafke N. 2011. Does government ideology influence budget composition? Empirical evidence from OECD countries. Economics of Governance 12: 101-34.

Reinhart CM., Rogoff KS. 2010a. Growth in a time of debt. American Economic Review: Papers $\&$ Proceedings 100: 573-78. 
Reinhart CM., Rogoff KS. 2010b. Growth in a time of debt. National Bureau of Economic Research Working Paper 15639. Accessible at: http://www.nber.org/ papers/w15639

Rodrik D. 1998. Why do more open economies have bigger governments? Journal of Political Economy 106: 997-1032.

Rogoff K. 1990. Equilibrium political budget cycles. American Economic Review 80: 21-36.

Rogoff K., Sibert A. 1988. Elections and macroeconomic policy cycles. Review of Economic Studies 55: 1-16.

Sanz I., Velazquez FJ. 2007. The role of ageing in the growth of government and social welfare spending. European Journal of Political Economy 23: 917-931.

Shelton CA. 2007. The size and composition of government expenditure. Journal of Public Economics 91: 2230-2260.

Swank D., Steinmo S. 2002. The new political economy of taxation in advanced capitalist democracies. American Journal of Political Science 46: 642-655

Tepe M., Vanhuysse, P. 2009. Are ageing OECD welfare states on the path to gerontocracy? Evidence from 18 democracies, 1980-2002. Journal of Public Policy 29: $1-28$.

Tsebelis G. 1995. Decision making in political systems: veto players in presidentialism, parliamentarism, multicamerialism and multipartyism. British Journal of Political Science 25: 289-325.

Tsebelis G. 2002. Veto Players: How Political Institutions Work. Princeton: Princeton University Press.

Tsebelis G., Chang ECC. 2004. Veto players and the structure of the budget in advanced industrialized countries. European Journal of Political Research 43: 449-476.

Volkerink B., De Haan JD. 1999. Political and Institutional Determinants of the Tax Mix: An Empirical Investigation for OECD countries. Groningen: University of Groningen.

Volkerink B., De Haan JD. 2001. Fragmented government effects on fiscal policy: New evidence. Public Choice 109: 221-242.

Wang C., Caminada K., Goudswaard K. 2012. The redistributive effect of social transfer programs and taxes: A decomposition across countries. International Social Security Review 65: 27-48.

Wang C., Caminada K., Goudswaard K. 2014. Income redistribution in 20 countries over time. International Journal of Social Welfare 23: 262-275. 
Westerlund J. 2007. Testing for error correction in panel data, Oxford Bulletin of Economics and Statistics 69: 709-748.

World Bank. 2015. World Bank Development Indicators. Retrieved March 21, 2015. Accessible at: http://databank.worldbank.org/data/home.aspx 


\section{Appendix}

\section{Panel unit root and cointegration tests}

Diagnostic results from testing for unit roots are documented in Table 8. Panel unit root tests indicated with 'LLC', 'BD', 'HS' and 'DH' refer to Levin, Lin and Chu (2002), Breitung and Das (2005), Herwartz and Siedenburg (2008) and Demetrescu and Hanck (2012), respectively. Among these tests 'HS' and 'DH' have been shown to be robust to time varying covariances under suitable conditions. As it turns out, allowing for a deterministic trend in the considered time series, DH and HS indicate non-stationarity of all considered macroeconomic and demographic variables (PE, GDP, UE, DR, NX, TRADE, SURP). Allowing only for non-zero expectations under the alternative hypothesis (excluding the linear trend), unemployment rates (UE) and budget surpluses (SURP) are diagnosed stationary, while testing for a panel unit root to govern the dependency ratio (DR) obtains mixed evidence (HS and DH are significant and insignificant, respectively, at the nominal $5 \%$ level). In summary, stochastic trends are most likely to govern the dynamic patterns of PE, GDP, NX and TRADE. In line with economic intuition, budget surplus can be considered panel stationary. While PURT diagnostics (partly) hint at stationarity of UE and DR, we consider these variables to eventually cointegrate with PE as both correspond to important categories of public spending.

We test for panel cointegration by means of the ECM test in Westerlund (2007). As it turns out, specifying ECMs for adjustments $\triangle P E$, the null hypothesis of no cointegration can be rejected in systems comprising three trending variables, either PE, GDP and UE or PE, GDP and DR. ${ }^{25}$ Using alternative test statistics (based on mean-group or pooled panel estimation), seven out of eight robust $p$-values documented in Table 9 indicate cointegration with at least 10\% significance. Interestingly, unreported results from cointegration testing allow two further conclusions: First, the test statistics do not provide evidence in favour of cointegration (error correction) if either the changes of GDP, UE or DR are employed as left-hand-side variables of the test regression. Hence, these variables do not respond to violations of the equilibrium relation among $\mathrm{PE}$ and its presumed long-term fundamentals. Secondly, with adjustments of PE as the dependent variable, cointegration cannot be diagnosed in systems where all long-term determinants of $\mathrm{PE}$ enter the equilibrium relation jointly. This result might reflect power weaknesses of the ECM test given the small time dimension of the panel $(T=34)$.

\section{Long-run evolvement of public expenditure}

Table 10 shows mean-group estimates of the long-run parameters in (1) and corresponding $t$-ratios. At the mean-group level, deterministic trends lack significance. The average longrun parameter estimates of real per capita GDP and unemployment are both positive and significant. As a consequence of multicollinearity, it is likely that country-specific regressions of stochastically trending level variables do not uncover well distinguished marginal effects to the employed trending variables (GDP, UN, DR and the linear trend). A par-

\footnotetext{
${ }^{25}$ For bivariate systems comprising $\mathrm{PE}$ and one other trending variable the null hypothesis of no cointegration can also be rejected at common significance levels.
} 
ticular important effect can be diagnosed for the level of public expenditures during the (ongoing) financial and sovereign debt crises. The coefficient of the time dummy variable D07 is significant and implies that, ceteris paribus, public expenditures are, on average, about $6 \%$ higher during the crisis period. This considerable shift is perhaps best understood against the background of measures undertaken to stabilize the banking/financial sector in several major economies.

Since all time series entering the static OLS regressions are integrated of order one, mean-group diagnostics support the existence of a stable long-run relation. From results in Phillips and Moon (1999) one can argue that (at the panel level) MG estimates and $t$-ratios are suitably immunized against effects of single equation spurious regressions. In summary, the flexible (i.e., country-specific) model representation in (1) allows to figure out important similarities in the international shape of public expenditures. In addition, unreported results show that the static regressions are effective to filter out transitory deviations from the long-run equilibrium. 


\begin{tabular}{|c|c|c|c|}
\hline Variable & "Definition & "Measurement & Source \\
\hline $\mathrm{PE}$ & $\begin{array}{l}\text { Public Expendi- } \\
\text { ture }\end{array}$ & $\begin{array}{l}\text { Per capita in US dollar and } \\
\text { US purchasing power parity } \\
\text { in natural logarithms }\end{array}$ & $\begin{array}{l}\text { EWI (2015), EUROSTAT } \\
(2015) \text { for values after 2010, } \\
\text { OECD (2015c) for AUS, CAN, } \\
\text { JPN, NZL, US }\end{array}$ \\
\hline SE & $\begin{array}{l}\text { Social Expendi- } \\
\text { ture }\end{array}$ & $\begin{array}{l}\text { Per capita in US dollar and } \\
\text { US purchasing power parity } \\
\text { in natural logarithms }\end{array}$ & $\begin{array}{l}\text { OECD (2015b), Social Expen- } \\
\text { diture Database }\end{array}$ \\
\hline NSE & $\begin{array}{l}\text { 'Non-social' ex- } \\
\text { penditure }\end{array}$ & $\begin{array}{l}\text { Per capita in US dollar and } \\
\text { US purchasing power parity } \\
\text { in natural logarithms (NSE } \\
=\mathrm{PE}-\mathrm{SE} \text { ) }\end{array}$ & Own calculations \\
\hline GDP & $\begin{array}{l}\text { Gross Domestic } \\
\text { Product }\end{array}$ & $\begin{array}{l}\text { Per capita in US dollar and } \\
\text { US purchasing power parity } \\
\text { in natural logarithms }\end{array}$ & $\begin{array}{l}\text { OECD } \\
\text { Database }\end{array}$ \\
\hline UE & $\begin{array}{l}\text { Unemployment } \\
\text { rate }\end{array}$ & $\begin{array}{l}\text { Share of unemployed over } \\
\text { total labor force }\end{array}$ & $\begin{array}{l}\text { OECD } \\
\text { Database }\end{array}$ \\
\hline $\mathrm{P} 15$ & $\begin{array}{l}\text { Ratio of young } \\
(<15) \text { over total } \\
\text { population }\end{array}$ & $\begin{array}{l}\text { OECD (2015a), Health } \\
\text { Database }\end{array}$ & \\
\hline P65 & $\begin{array}{l}\text { Ratio of elder } \\
(>65) \text { over total } \\
\text { population }\end{array}$ & $\begin{array}{l}\text { OECD (2015a), Health } \\
\text { Database }\end{array}$ & \\
\hline DR & Dependency rate & $\begin{array}{l}\text { Ratio of young }(<15) \text { and } \\
\text { elder }(>65) \text { over total pop- } \\
\text { ulation }(\mathrm{DP}=\mathrm{P} 15+\mathrm{P} 65)\end{array}$ & $\begin{array}{l}\text { OECD } \\
\text { Database }\end{array}$ \\
\hline NX & Net exports & Percentage of GDP & $\begin{array}{l}\text { World Bank (2015), World De- } \\
\text { velopment Indicators }\end{array}$ \\
\hline TRADE & $\begin{array}{l}\text { Sum of exports } \\
\text { and imports }\end{array}$ & Percentage of GDP & $\begin{array}{l}\text { World Bank (2015), World De- } \\
\text { velopment Indicators }\end{array}$ \\
\hline SURP & $\begin{array}{l}\text { General govern- } \\
\text { ment surplus }\end{array}$ & Percentage of GDP & $\begin{array}{l}\text { OECD (2015c), Main Eco- } \\
\text { nomic Indicators Database }\end{array}$ \\
\hline DEBT90 & $\begin{array}{l}\text { Dummy for } \\
\text { excessive gov- } \\
\text { ernment debt }\end{array}$ & $\begin{array}{l}\text { One if gross general govern- } \\
\text { ment debt is above } 90 \% \text { of } \\
\text { GDP, zero else }\end{array}$ & $\begin{array}{l}\text { Abbas et al. (2010), IMF } \\
\text { (2012), Historical Public Debt } \\
\text { Database, OECD (2015c), } \\
\text { Main Economic Indicators } \\
\text { Database. }\end{array}$ \\
\hline D07 & Time dummy & $\begin{array}{l}\text { One after institutional } \\
\text { break in } 2007 \text {, zero else }\end{array}$ & Own calculation \\
\hline
\end{tabular}

Table 1: Data definitions and sources. 


\begin{tabular}{|c|c|c|c|}
\hline Variable & Definition & Measurement & Source \\
\hline IDEO & $\begin{array}{l}\text { (Unweighted) } \\
\text { mean ideology } \\
\text { position of the } \\
\text { coalition in } \\
\text { government }\end{array}$ & $\begin{array}{l}\text { Between }-5 \text { (extreme left) } \\
\text { and } 5 \text { (extreme right posi- } \\
\text { tions) }\end{array}$ & $\begin{array}{l}\text { Döring and Manow (2001), } \\
\text { Parliament and Government } \\
\text { Composition Database (Par- } \\
\text { Gov); Data for the US is from } \\
\text { Benoit and Laver (2006) }\end{array}$ \\
\hline ELEC & Election date & $\begin{array}{l}\text { Date of election as time } \\
\text { share over year in election } \\
\text { years, zero in years without } \\
\text { elections }\end{array}$ & Own calculation \\
\hline POLA & $\begin{array}{l}\text { Party polariza- } \\
\text { tion index }\end{array}$ & & $\begin{array}{l}\text { Own calculations based } \\
\text { on data from Döring and } \\
\text { Manow (2001), Parliament } \\
\text { and Government Composition } \\
\text { Database (ParGov) and data } \\
\text { (for the US) from Benoit and } \\
\text { Laver (2006) }\end{array}$ \\
\hline $\mathrm{NCP}$ & $\begin{array}{l}\text { Number of coali- } \\
\text { tion partners }\end{array}$ & Integer number & $\begin{array}{l}\text { Döring and Manow (2001), } \\
\text { Parliament and Government } \\
\text { Composition Database (Par- } \\
\text { Gov) }\end{array}$ \\
\hline
\end{tabular}

Table 1: Continued. Data definitions and sources. 


\begin{tabular}{|c|c|c|c|c|c|c|c|c|c|c|c|c|c|c|c|}
\hline \multirow{2}{*}{$\begin{array}{l}\text { Var } \\
\text { PE }\end{array}$} & \multicolumn{2}{|c|}{$\overline{M i n}$} & \multicolumn{2}{|c|}{ Max } & \multirow{2}{*}{$\begin{array}{c}\text { Mean } \\
9.49\end{array}$} & \multirow{2}{*}{$\begin{array}{c}\sigma_{\text {betw }} \\
0.25\end{array}$} & \multirow{2}{*}{$\begin{array}{c}\sigma_{\text {with }} \\
0.30\end{array}$} & \multirow{2}{*}{$\begin{array}{l}\text { Var } \\
\Delta \mathrm{PE}\end{array}$} & \multicolumn{2}{|c|}{ Min } & \multicolumn{2}{|c|}{ Max } & \multirow{2}{*}{$\begin{array}{l}\text { Mean } \\
0.017\end{array}$} & \multirow{2}{*}{$\begin{array}{c}\sigma_{\text {betw }} \\
0.006\end{array}$} & \multirow{2}{*}{$\begin{array}{l}\sigma_{\text {with }} \\
0.038\end{array}$} \\
\hline & 9.10 & PRT & 9.90 & LUX & & & & & 0.002 & NZL & 0.027 & $\overline{L U X}$ & & & \\
\hline NSE & 8.40 & ESP & 9.25 & NOR & 8.85 & 0.24 & 0.29 & $\Delta \mathrm{NSE}$ & -0.020 & NZL & 0.029 & GRC & 0.007 & 12 & 051 \\
\hline UE & 2.69 & LUX & 17.1 & ESP & 7.51 & 3.17 & 4.07 & $\Delta \mathrm{UE}$ & -0.071 & DNK & 0.638 & GRC & 0.112 & 0.157 & 1.108 \\
\hline DR & 31.57 & CAN & 35.7 & IRL & 33.5 & 1. & 1.7 & $\Delta \mathrm{DR}$ & -0.203 & IRL & 0.164 & JPN & -0.032 & 0.073 & 0.259 \\
\hline P65 & 11.18 & IRL & 17.5 & SWE & 14.6 & 1.86 & 2.57 & $\Delta \mathrm{P} 65$ & 0.006 & LUX & 0.485 & JPN & 0.148 & 0.102 & 0.186 \\
\hline TRADH & 22.55 & US & 239.2 & LUX & 73.9 & 48.5 & 50.8 & $\Delta$ TRADH & -0.405 & NOR & 6.134 & LUX & 0.996 & 1.367 & 5.395 \\
\hline SURP & -7.77 & GRC & 8.20 & NOR & -2.68 & 3.39 & 4.88 & DEBT90 & 0.000 &.-- & 0.857 & BEL & 0.180 & 0.275 & 0.384 \\
\hline IDEO & -0.409 & SWE & 2.283 & $\mathrm{JPN}$ & 0.503 & 0.594 & 1.556 & ELEC & 0.07 & FIN & 0.26 & NZL & 0.16 & 0.06 & 0.30 \\
\hline POLA & 0.23 & BEL & 1.11 & US & 0.50 & 0.18 & 0.19 & $\mathrm{NCP}$ & 1.000 &.-- & 4.706 & BEL & 2.144 & 1.085 & 1.271 \\
\hline
\end{tabular}

Table 2: Descriptive statistics. The panel covers the time period 1980-2013 and consists of 21 economies, Australia (AUS), Austria (AUT), Belgium (BEL), Canada (CAN), Denmark (DNK), Finland (FIN), France (FRA), Germany (GER), Greece (GRC), Ireland (IRL), Italy (ITA), Japan (JPN), Luxembourg (LUX), the Netherlands (NLD), New Zealand (NZL), Norway (NOR), Portugal (PRT), Spain (ESP), Sweden (SWE), the United Kingdom (UK), and the United States (US). With regard to NCP, CAN, ESP and US have the minimum mean of 1. With regard to DEBT90, 10 economies have not experienced levels of debt in excess of $90 \%$ of GDP (AUS, AUT, GER, DNK, FIN, NLD, NOR, NZL, LUX and SWE). 


\begin{tabular}{|c|c|c|c|c|c|c|c|}
\hline & \multicolumn{2}{|c|}{$\triangle \overline{\mathrm{PE}}$} & \multicolumn{2}{|c|}{$\triangle \mathrm{SE}$} & \multicolumn{2}{|c|}{$\Delta \mathrm{NSE}$} & ' $\Delta \mathrm{SE}-\Delta \mathrm{NSE} '$ \\
\hline & est & $\bar{R}^{2}$ & est & $\bar{R}^{2}$ & est & $\bar{R}^{2}$ & est \\
\hline & \multicolumn{7}{|c|}{ Restricted model (standard ECM for $\Delta \mathrm{PE}, \gamma=0$ ) } \\
\hline$R^{2}$ & \multicolumn{2}{|c|}{26.4} & \multicolumn{2}{|c|}{22.1} & \multicolumn{2}{|c|}{14.2} & \\
\hline$\hat{\nu}_{U S}$ & $\begin{array}{c}0.021 \\
\left(7.48^{* *}\right)\end{array}$ & 22.4 & $\begin{array}{l}0.028 \\
\left(9.81^{* *}\right)\end{array}$ & 34.6 & $\begin{array}{c}0.011 \\
\left(2.76^{* *}\right)\end{array}$ & 15.6 & $\begin{array}{c}0.017 \\
\left(3.41^{* *}\right)\end{array}$ \\
\hline$\hat{\delta}_{U S}$ & $\begin{array}{l}-0.037 \\
\left(-3.31^{* *}\right)\end{array}$ & 10.9 & $\begin{array}{l}-0.059 \\
\left(-4.93^{* *}\right)\end{array}$ & 14.1 & $\begin{array}{c}-0.025 \\
(-1.34)\end{array}$ & 17.1 & $\begin{array}{l}-0.034 \\
(-1.53)\end{array}$ \\
\hline$\hat{\alpha}_{U S}$ & $\begin{array}{l}-0.137 \\
\left(-3.81^{* *}\right)\end{array}$ & 28.5 & $\begin{array}{l}-0.038 \\
\left(-2.08^{* *}\right)\end{array}$ & 20.1 & $\begin{array}{l}-0.128 \\
\left(-2.76^{* *}\right)\end{array}$ & 31.4 & $\begin{array}{l}0.090 \\
\left(1.80^{*}\right)\end{array}$ \\
\hline \multirow[t]{2}{*}{$\hat{\phi}_{U S}$} & $\begin{array}{c}0.370 \\
\left(8.56^{* *}\right)\end{array}$ & 38.2 & $\begin{array}{c}0.279 \\
\left(7.12^{* *}\right)\end{array}$ & 31.2 & $\begin{array}{c}0.204 \\
\left(4.73^{* *}\right)\end{array}$ & 35.9 & $\begin{array}{c}0.074 \\
(1.27)\end{array}$ \\
\hline & \multicolumn{7}{|c|}{ Unrestricted model (augmented ECM for $\Delta$ PE, $\gamma \neq 0$ ) } \\
\hline$R^{2}$ & \multicolumn{2}{|c|}{37.0} & \multicolumn{2}{|c|}{40.8} & \multicolumn{2}{|c|}{28.3} & \\
\hline$\hat{\nu}_{U S}$ & $\begin{array}{c}0.036 \\
\left(5.65^{* *}\right)\end{array}$ & 21.1 & $\begin{array}{c}0.049 \\
\left(7.42^{* *}\right)\end{array}$ & 21.0 & $\begin{array}{c}0.023 \\
\left(2.05^{* *}\right)\end{array}$ & 24.1 & $\begin{array}{c}0.027 \\
\left(2.09^{* *}\right)\end{array}$ \\
\hline$\hat{\delta}_{U S}$ & $\begin{array}{l}-0.081 \\
\left(-4.59^{* *}\right)\end{array}$ & 13.5 & $\begin{array}{l}-0.098 \\
\left(-5.30^{* *}\right)\end{array}$ & 23.0 & $\begin{array}{l}-0.060 \\
\left(-2.00^{* *}\right)\end{array}$ & 19.9 & $\begin{array}{l}-0.038 \\
(-1.08)\end{array}$ \\
\hline$\hat{\alpha}_{U S}$ & $\begin{array}{l}-0.067 \\
\left(-2.20^{* *}\right)\end{array}$ & 23.4 & $\begin{array}{c}-0.026 \\
(-1.42)\end{array}$ & 10.7 & $\begin{array}{c}-0.074 \\
(-1.57)\end{array}$ & 10.1 & $\begin{array}{c}0.048 \\
(0.94)\end{array}$ \\
\hline$\hat{\phi}_{U S}$ & $\begin{array}{r}0.280 \\
\left(6.52^{* *}\right) \\
\end{array}$ & 16.5 & $\begin{array}{l}0.162 \\
\left(3.95^{* *}\right) \\
\end{array}$ & 11.8 & $\begin{array}{l}0.079 \\
\left(1.83^{*}\right) \\
\end{array}$ & 9.36 & $\begin{array}{c}0.084 \\
(1.40) \\
\end{array}$ \\
\hline
\end{tabular}

Table 3: Estimation results ( $t$-ratios in parentheses) for parameters describing the US benchmark economy. The upper and lower panel show results for the restricted ECM (excluding $\boldsymbol{z}_{i t}, \boldsymbol{\gamma}=0$ ) and unrestricted (including $\boldsymbol{z}_{i t}, \boldsymbol{\gamma} \neq 0$ ), respectively. Coefficients of the linear trend have been multiplied with 100 . ' $*$ ' and ' $* *$ ' indicate $t$-ratios (parameter estimates) that are significant at the $10 \%$ and $5 \%$ level, respectively. The column ' $\bar{R}^{2}$, , documents in percentage points the contribution of fixed effects, linear trends, error correction and autoregressive dynamics (aggregated over all economies) to the partial degrees of explanation summed over all employed explanatory variables. For notes on the panel composition see Table 2 . 


\begin{tabular}{|c|c|c|c|c|c|c|c|c|c|c|c|c|}
\hline & \multicolumn{3}{|c|}{$\hat{\nu}_{i}$} & \multicolumn{3}{|c|}{$\overline{\hat{\delta}_{i}}$} & \multicolumn{3}{|c|}{$\overline{\hat{\alpha}_{i}}$} & \multicolumn{3}{|c|}{$\overline{\hat{\phi}_{i}}$} \\
\hline & $\Delta \mathrm{PE}$ & $\Delta \mathrm{SE}$ & $\Delta \mathrm{NSE}$ & $\Delta \mathrm{PE}$ & $\Delta \mathrm{SE}$ & $\Delta \mathrm{NSE}$ & $\Delta \mathrm{PE}$ & $\Delta \mathrm{SE}$ & $\Delta \mathrm{NSE}$ & $\Delta \mathrm{PE}$ & $\Delta \mathrm{SE}$ & $\Delta \mathrm{NSE}$ \\
\hline AUS &.-- &.-- &.-- &.-- &.-- &.-- & $\begin{array}{c}-0.523 \\
(-2.79)\end{array}$ &.-- &.-- &.-- &.-- &.-- \\
\hline AUT &.-- & -.- &.-- &.-- & $\begin{array}{c}-0.041 \\
(-2.75)\end{array}$ &.-- &.-- &.-- &.-- &.-- &.-- &.-- \\
\hline BEL & $\begin{array}{c}0.029 \\
(3.39)\end{array}$ & $\begin{array}{c}0.015 \\
(2.10)\end{array}$ & $\begin{array}{c}0.023 \\
(2.16)\end{array}$ &.-- &.-- &.-- & $\begin{array}{c}-0.369 \\
(-2.20)\end{array}$ &.-- & $\begin{array}{c}0.551 \\
(2.00)\end{array}$ &.-- & $\begin{array}{c}-0.542 \\
(-3.08)\end{array}$ & $\begin{array}{c}-0.666 \\
(-3.07)\end{array}$ \\
\hline CAN &.-- &.-- & $\begin{array}{c}0.031 \\
(2.18)\end{array}$ &.-- & $\begin{array}{c}-0.051 \\
(-2.25)\end{array}$ & $\begin{array}{c}-0.140 \\
(-2.03)\end{array}$ &.-- &.-- &.-- &.-- &.-- &.-- \\
\hline DNK &.-- &.-- &.-- & $\begin{array}{c}-0.052 \\
(-2.15)\end{array}$ & $\begin{array}{c}-0.087 \\
(-3.80)\end{array}$ & $\begin{array}{c}-0.058 \\
(-1.84)\end{array}$ & $\begin{array}{c}-0.471 \\
(-3.14)\end{array}$ & $\begin{array}{c}-0.237 \\
(-1.88)\end{array}$ &.-- &.-- &.-- &.-- \\
\hline ESP & $\begin{array}{c}0.037 \\
(2.39)\end{array}$ & -.- & $\begin{array}{c}0.105 \\
(4.41)\end{array}$ & $\begin{array}{c}-0.120 \\
(-1.95)\end{array}$ &.-- & $\begin{array}{c}-0.428 \\
(-4.14)\end{array}$ &.-- &.-- &.-- & $\begin{array}{c}-0.405 \\
(-2.42)\end{array}$ &.-- & $\begin{array}{c}-0.642 \\
(-3.21)\end{array}$ \\
\hline FIN &.-- &.-- &.-- &.-- & $\begin{array}{c}-0.074 \\
(-2.87)\end{array}$ &.-- & $\begin{array}{c}-0.684 \\
(-4.22)\end{array}$ & $\begin{array}{c}-0.287 \\
(-3.26)\end{array}$ &.-- &.-- &.-- &.-- \\
\hline FRA &.-- & $\begin{array}{c}0.034 \\
(2.44)\end{array}$ &.-- &.-- & $\begin{array}{c}-0.142 \\
(-2.57)\end{array}$ &.-- & $\begin{array}{c}0.391 \\
(1.87)\end{array}$ & $\begin{array}{c}1.007 \\
(2.78)\end{array}$ &.-- &.-- & $\begin{array}{c}-0.463 \\
(-2.61)\end{array}$ &.-- \\
\hline GER &.-- &.-- &.-- &.-- & $\begin{array}{c}-0.080 \\
(-3.13)\end{array}$ &.-- &.-- &.-- &.-- & $\begin{array}{c}-0.490 \\
(-2.96)\end{array}$ &.-- & $\begin{array}{c}-0.494 \\
(-2.72)\end{array}$ \\
\hline GRC & $\begin{array}{c}0.038 \\
(4.11)\end{array}$ & -.- & $\begin{array}{c}0.048 \\
(3.24)\end{array}$ &.-- &.-- & -.- & -.- &.-- &.-- & $\begin{array}{c}-0.348 \\
(-2.48)\end{array}$ &.-- &.-- \\
\hline
\end{tabular}

Table 4: Estimates of country specific parameters within the policy augmented ECM in (2) as deviations from the US benchmark. The model dimension has been reduced by iteratively removing parameters with weakest significance until remaining model parameters share 10\% nominal significance. US benchmark parameters are not subjected to model reduction steps. Imposed restrictions are jointly insignificant according to respective $F$-tests ( $p$ values are close to unity). 


\begin{tabular}{|c|c|c|c|c|c|c|c|c|c|c|c|c|}
\hline & \multicolumn{3}{|c|}{$\hat{\nu}_{i}$} & \multicolumn{3}{|c|}{$\hat{\delta}_{i}$} & \multicolumn{3}{|c|}{$\hat{\alpha}_{i}$} & \multicolumn{3}{|c|}{$\hat{\phi}_{i}$} \\
\hline & $\Delta \mathrm{PE}$ & $\Delta \mathrm{SE}$ & $\Delta \mathrm{NSE}$ & $\Delta \mathrm{PE}$ & $\Delta \mathrm{SE}$ & $\Delta \mathrm{NSE}$ & $\Delta \mathrm{PE}$ & $\Delta \mathrm{SE}$ & $\Delta \mathrm{NSE}$ & $\Delta \mathrm{PE}$ & $\Delta \mathrm{SE}$ & $\Delta \mathrm{NSE}$ \\
\hline IRL &.-- & -.- &.-- & $\begin{array}{l}0.122 \\
(3.27)\end{array}$ &.-- & $\begin{array}{c}0.117 \\
(2.26)\end{array}$ & -.- & -.- &.-- &.-- & $\begin{array}{c}0.282 \\
(2.39)\end{array}$ &.-- \\
\hline ITA & $\begin{array}{c}0.078 \\
(4.37)\end{array}$ & $\begin{array}{c}0.041 \\
(3.16)\end{array}$ & $\begin{array}{c}0.090 \\
(3.90)\end{array}$ & $\begin{array}{c}-0.262 \\
(-3.36)\end{array}$ & $\begin{array}{c}-0.152 \\
(-2.88)\end{array}$ & $\begin{array}{c}-0.342 \\
(-3.27)\end{array}$ & -.- &.-- & -.- & $\begin{array}{c}-0.390 \\
(-2.02)\end{array}$ & $\begin{array}{c}-0.330 \\
(-2.15)\end{array}$ & -.- \\
\hline JPN & $\begin{array}{c}0.031 \\
(3.28)\end{array}$ & $\begin{array}{c}0.017 \\
(2.72)\end{array}$ & -.- & -.- & -.- & -.- & -.- &.-- & $\begin{array}{c}-0.990 \\
(-3.03)\end{array}$ & $\begin{array}{c}-0.684 \\
(-4.21)\end{array}$ &.-- & $\begin{array}{c}-0.292 \\
(-2.55)\end{array}$ \\
\hline LUX & -.- & -.- &.-- &.-- &.-- & -.- & $\begin{array}{c}-0.568 \\
(-4.32)\end{array}$ & $\begin{array}{c}-0.320 \\
(-2.34)\end{array}$ & $\begin{array}{c}-0.597 \\
(-2.46)\end{array}$ & -.- & $\begin{array}{c}-0.249 \\
(-2.18)\end{array}$ & -.- \\
\hline NLD &.-- & $\begin{array}{c}-0.014 \\
(-2.61)\end{array}$ &.-- &.-- & -.- &.-- & -.- &.-- &.-- &.-- &.-- &.-- \\
\hline NOR &.-- & $\begin{array}{c}0.064 \\
(2.60)\end{array}$ &.-- & $\begin{array}{c}-0.121 \\
(-3.45)\end{array}$ & $\begin{array}{c}-0.428 \\
(-4.01)\end{array}$ & $\begin{array}{c}-0.201 \\
(-4.42)\end{array}$ & $\begin{array}{c}-0.380 \\
(-2.97)\end{array}$ & $\begin{array}{l}-0.548 \\
(-3.24)\end{array}$ & $\begin{array}{c}-0.802 \\
(-3.80)\end{array}$ &.-- &.-- &.-- \\
\hline NZL & $\begin{array}{c}-0.077 \\
(-3.90)\end{array}$ & $\begin{array}{c}-0.017 \\
(-2.89)\end{array}$ & $\begin{array}{c}-0.025 \\
(-2.46)\end{array}$ & $\begin{array}{c}0.301 \\
(3.34)\end{array}$ &.-- &.-- & $\begin{array}{c}-0.520 \\
(-3.49)\end{array}$ &.-- & -.- & $\begin{array}{c}-0.476 \\
(-3.36)\end{array}$ &.-- &.-- \\
\hline PRT &.-- & $\begin{array}{c}0.061 \\
(3.86)\end{array}$ &.-- &.-- & $\begin{array}{c}-0.207 \\
(-3.19)\end{array}$ & -.- & $\begin{array}{c}-0.484 \\
(-3.42)\end{array}$ & $\begin{array}{c}-0.397 \\
(-3.11)\end{array}$ & $\begin{array}{c}-0.595 \\
(-1.95)\end{array}$ &.-- &.-- &.-- \\
\hline SWE &.-- &.-- &.-- &.-- & $\begin{array}{c}-0.088 \\
(-3.75)\end{array}$ & $\begin{array}{c}-0.086 \\
(-1.84)\end{array}$ & $\begin{array}{c}-0.742 \\
(-3.80)\end{array}$ &.-- &.-- &.-- &.-- &.-- \\
\hline
\end{tabular}

Table 4: Continued. Estimates of country specific parameters within the policy augmented ECM in (2) as deviations from the US benchmark. 


\begin{tabular}{|c|c|c|c|c|c|c|c|}
\hline & \multicolumn{2}{|c|}{$\overline{\Delta P E}$} & \multicolumn{2}{|c|}{$\triangle \mathrm{SE}$} & \multicolumn{2}{|c|}{$\Delta \mathrm{NSE}$} & \multirow{2}{*}{$\begin{array}{l}\Delta \text { SE- }-\mathrm{NSE}^{\prime} \\
\hat{\phi}_{\triangle S E}-\hat{\phi}_{\Delta N S E}\end{array}$} \\
\hline & $\hat{\phi}$ & $\bar{R}^{2}$ & $\hat{\phi}$ & $\bar{R}^{2}$ & $\hat{\phi}$ & $\bar{R}^{2}$ & \\
\hline & \multicolumn{7}{|c|}{ Economic effects } \\
\hline$\Delta \mathrm{GDP}$ & $\begin{array}{c}0.071 \\
(0.92)\end{array}$ & 1.03 & $\begin{array}{c}0.062 \\
(0.88)\end{array}$ & 0.15 & $\begin{array}{l}0.243 \\
\left(2.04^{* *}\right)\end{array}$ & 1.77 & $\begin{array}{c}-0.181 \\
(-1.30)\end{array}$ \\
\hline$\Delta \mathrm{UE}$ & $\begin{array}{c}0.159 \\
(1.05)\end{array}$ & 0.34 & $\begin{array}{c}0.196 \\
(1.46)\end{array}$ & 0.01 & $\begin{array}{l}0.597 \\
\left(2.58^{* *}\right)\end{array}$ & 2.62 & $\begin{array}{c}-0.401 \\
(-1.50)\end{array}$ \\
\hline$\Delta \mathrm{P} 15$ & $\begin{array}{l}1.141 \\
\left(1.71^{*}\right)\end{array}$ & 0.10 & $\begin{array}{l}1.422 \\
\left(2.34^{* *}\right)\end{array}$ & 0.87 & $\begin{array}{c}1.433 \\
(1.28)\end{array}$ & 0.02 & $\begin{array}{c}-0.011 \\
(-0.01)\end{array}$ \\
\hline$\Delta \mathrm{P} 65$ & $\begin{array}{l}2.138 \\
\left(2.73^{* *}\right)\end{array}$ & 0.85 & $\begin{array}{l}3.137 \\
\left(4.12^{* *}\right)\end{array}$ & 4.61 & $\begin{array}{c}-0.717 \\
(-0.59)\end{array}$ & 0.35 & $\begin{array}{l}3.854 \\
\left(2.69^{* *}\right)\end{array}$ \\
\hline$\Delta \mathrm{NX}$ & $\begin{array}{c}-0.137 \\
(-1.60)\end{array}$ & 0.77 & $\begin{array}{l}-0.225 \\
\left(-2.68^{* *}\right)\end{array}$ & 1.98 & $\begin{array}{l}-0.357 \\
\left(-2.64^{* *}\right)\end{array}$ & 2.20 & $\begin{array}{c}0.132 \\
(0.83)\end{array}$ \\
\hline$\triangle \mathrm{TRADE}$ & $\begin{array}{c}-0.031 \\
(-1.26)\end{array}$ & 0.40 & $\begin{array}{l}-0.053 \\
\left(-2.60^{* *}\right)\end{array}$ & 0.99 & $\begin{array}{c}-0.056 \\
(-1.44)\end{array}$ & 1.40 & $\begin{array}{c}0.004 \\
(0.09)\end{array}$ \\
\hline$\Delta \mathrm{SURP}$ & $\begin{array}{c}0.231 \\
\left(6.00^{* *}\right)\end{array}$ & 5.66 & $\begin{array}{c}0.249 \\
\left(7.51^{* *}\right)\end{array}$ & 9.63 & $\begin{array}{c}0.354 \\
\left(6.05^{* *}\right)\end{array}$ & 11.3 & $\begin{array}{c}-0.105 \\
(-1.56)\end{array}$ \\
\hline DEBT90 & $\begin{array}{l}-0.018 \\
\left(-3.82^{* *}\right)\end{array}$ & 2.29 & $\begin{array}{l}-0.009 \\
\left(-2.36^{* *}\right)\end{array}$ & 0.40 & $\begin{array}{l}-0.015 \\
\left(-2.33^{* *}\right)\end{array}$ & 1.83 & $\begin{array}{c}0.006 \\
(0.78)\end{array}$ \\
\hline \multirow[t]{2}{*}{ D07 } & $\begin{array}{c}0.015 \\
\left(3.86^{* *}\right) \\
\end{array}$ & 2.62 & $\begin{array}{c}0.012 \\
\left(3.41^{* *}\right)\end{array}$ & 1.56 & $\begin{array}{l}0.026 \\
\left(4.19^{* *}\right) \\
\end{array}$ & 2.72 & $\begin{array}{l}-0.014 \\
\left(-1.99^{* *}\right)\end{array}$ \\
\hline & \multicolumn{7}{|c|}{ Political effects (coefficients multiplied with 100) } \\
\hline IDEO & $\begin{array}{c}-0.113 \\
(-0.36)\end{array}$ & 0.063 & $\begin{array}{c}-0.211 \\
(-0.67)\end{array}$ & 0.392 & $\begin{array}{c}-0.629 \\
(-1.25)\end{array}$ & 1.413 & $\begin{array}{c}0.418 \\
(0.71)\end{array}$ \\
\hline ELEC & $\begin{array}{l}0.568 \\
\left(1.69^{*}\right)\end{array}$ & 0.522 & $\begin{array}{c}0.648 \\
\left(2.11^{* *}\right)\end{array}$ & 1.422 & $\begin{array}{c}0.632 \\
(1.13)\end{array}$ & 0.261 & $\begin{array}{c}0.016 \\
(0.03)\end{array}$ \\
\hline POLA & $\begin{array}{c}-0.004 \\
(-0.01)\end{array}$ & 0.007 & $\begin{array}{c}0.118 \\
(0.17)\end{array}$ & 0.017 & $\begin{array}{c}0.517 \\
(0.49)\end{array}$ & 0.173 & $\begin{array}{c}-0.399 \\
(-0.31)\end{array}$ \\
\hline NCP & $\begin{array}{l}-0.337 \\
\left(-2.54^{* *}\right)\end{array}$ & 0.671 & $\begin{array}{c}-0.054 \\
(-0.42)\end{array}$ & 0.340 & $\begin{array}{c}-0.150 \\
(-0.78)\end{array}$ & 0.009 & $\begin{array}{c}0.096 \\
(0.42)\end{array}$ \\
\hline
\end{tabular}

Table 5: Estimation results for socio-economic and political variables ( $t$-ratios in parentheses). Conditioning variables listed in the upper panel are predetermined, i.e. lagged by one year. For further notes see Table 3 . 


\begin{tabular}{|c|c|c|c|c|c|c|c|}
\hline & \multicolumn{2}{|c|}{$\triangle \mathrm{PE}$} & \multicolumn{2}{|c|}{$\triangle \mathrm{SE}$} & \multicolumn{2}{|c|}{ 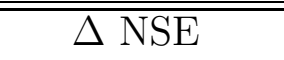 } & \multirow{2}{*}{$\begin{array}{l}' \Delta \mathrm{SE}-\Delta \mathrm{NSE}^{\prime} \\
\hat{\phi}_{\Delta S E}-\hat{\phi}_{\Delta N S E}\end{array}$} \\
\hline & $\hat{\phi}$ & $\bar{R}^{2}$ & $\hat{\phi}$ & $\bar{R}^{2}$ & $\hat{\phi}$ & $\bar{R}^{2}$ & \\
\hline & \multicolumn{7}{|c|}{ Economic interaction effects $S \times I D E O$} \\
\hline$\Delta \mathrm{GDP}^{+}$ & $\begin{array}{l}-0.170 \\
\left(-2.16^{* *}\right)\end{array}$ & 0.671 & $\begin{array}{c}0.003 \\
(0.04)\end{array}$ & 0.022 & $\begin{array}{l}-0.296 \\
\left(-2.29^{* *}\right)\end{array}$ & 1.393 & $\begin{array}{c}0.300 \\
\left(1.98^{* *}\right)\end{array}$ \\
\hline$\Delta \mathrm{GDP}^{-}$ & $\begin{array}{c}0.097 \\
(1.38)\end{array}$ & 0.424 & $\begin{array}{c}0.135 \\
\left(1.98^{* *}\right)\end{array}$ & 0.878 & $\begin{array}{c}0.101 \\
(0.88)\end{array}$ & 0.425 & $\begin{array}{c}0.034 \\
(0.25)\end{array}$ \\
\hline$\Delta \mathrm{UE}^{+}$ & $\begin{array}{l}-0.338 \\
\left(-2.41^{* *}\right)\end{array}$ & 0.637 & $\begin{array}{l}-0.440 \\
\left(-3.31^{* *}\right)\end{array}$ & 2.410 & $\begin{array}{c}-0.192 \\
(-0.88)\end{array}$ & 0.177 & $\begin{array}{c}-0.247 \\
(-0.96)\end{array}$ \\
\hline$\Delta \mathrm{UE}^{-}$ & $\begin{array}{c}0.108 \\
(0.82)\end{array}$ & 0.026 & $\begin{array}{c}-0.025 \\
(-0.19)\end{array}$ & 0.291 & $\begin{array}{c}0.088 \\
(0.40)\end{array}$ & 0.122 & $\begin{array}{c}-0.113 \\
(-0.44)\end{array}$ \\
\hline$\Delta \mathrm{P} 15^{+}$ & $\begin{array}{c}-0.614 \\
(-0.93)\end{array}$ & 0.133 & $\begin{array}{c}-0.492 \\
(-0.80)\end{array}$ & 0.013 & $\begin{array}{c}-0.466 \\
(-0.42)\end{array}$ & 0.058 & $\begin{array}{c}-0.026 \\
(-0.02)\end{array}$ \\
\hline$\Delta \mathrm{P} 15^{-}$ & $\begin{array}{c}-0.170 \\
(-0.21)\end{array}$ & 0.207 & $\begin{array}{c}-1.123 \\
(-1.45)\end{array}$ & 0.144 & $\begin{array}{l}1.835 \\
(1.41)\end{array}$ & 0.223 & $\begin{array}{l}-2.958 \\
\left(-1.95^{*}\right)\end{array}$ \\
\hline$\Delta \mathrm{P} 65^{+}$ & $\begin{array}{c}-2.395 \\
(-2.57)\end{array}$ & 0.264 & $\begin{array}{c}-1.534 \\
(-1.55)\end{array}$ & 0.252 & $\begin{array}{c}-2.458 \\
(-1.57)\end{array}$ & 0.141 & $\begin{array}{c}0.924 \\
(0.50)\end{array}$ \\
\hline$\Delta \mathrm{P} 65^{-}$ & $\begin{array}{c}1.117 \\
(1.28)\end{array}$ & 0.715 & $\begin{array}{l}3.185 \\
\left(3.13^{* *}\right)\end{array}$ & 2.761 & $\begin{array}{c}-0.126 \\
(-0.08)\end{array}$ & 0.081 & $\begin{array}{l}3.310 \\
\left(1.80^{*}\right)\end{array}$ \\
\hline$\Delta \mathrm{NX}^{+}$ & $\begin{array}{l}0.181 \\
\left(1.94^{*}\right)\end{array}$ & 0.815 & $\begin{array}{c}0.086 \\
(0.88)\end{array}$ & 0.540 & $\begin{array}{c}-0.005 \\
(-0.03)\end{array}$ & 0.033 & $\begin{array}{c}0.091 \\
(0.53)\end{array}$ \\
\hline$\Delta \mathrm{NX}^{-}$ & $\begin{array}{l}0.153 \\
\left(1.72^{*}\right)\end{array}$ & 1.560 & $\begin{array}{c}-0.141 \\
(-1.35)\end{array}$ & 0.063 & $\begin{array}{c}0.245 \\
(1.55)\end{array}$ & 1.608 & $\begin{array}{l}-0.385 \\
\left(-2.04^{* *}\right)\end{array}$ \\
\hline$\Delta \mathrm{TRADE}^{+}$ & $\begin{array}{c}-0.027 \\
(-0.86)\end{array}$ & 0.041 & $\begin{array}{c}0.003 \\
(0.09)\end{array}$ & 0.011 & $\begin{array}{c}-0.006 \\
(-0.12)\end{array}$ & 0.004 & $\begin{array}{c}0.009 \\
(0.15)\end{array}$ \\
\hline$\Delta \mathrm{TRADE}^{-}$ & $\begin{array}{c}-0.002 \\
(-0.08)\end{array}$ & 0.001 & $\begin{array}{c}-0.022 \\
(-0.78)\end{array}$ & 0.154 & $\begin{array}{c}-0.028 \\
(-0.61)\end{array}$ & 0.093 & $\begin{array}{c}0.006 \\
(0.11)\end{array}$ \\
\hline $\mathrm{SURP}^{+}$ & $\begin{array}{l}0.000 \\
(-0.01)\end{array}$ & 0.030 & $\begin{array}{c}0.040 \\
(1.08)\end{array}$ & 0.225 & $\begin{array}{c}-0.005 \\
(-0.09)\end{array}$ & 0.001 & $\begin{array}{c}0.044 \\
(0.67)\end{array}$ \\
\hline $\mathrm{SURP}^{-}$ & $\begin{array}{c}0.064 \\
(1.50)\end{array}$ & 0.073 & $\begin{array}{c}0.060 \\
(1.53)\end{array}$ & 0.251 & $\begin{array}{c}0.150 \\
\left(2.19^{* *}\right)\end{array}$ & 1.852 & $\begin{array}{c}-0.090 \\
(-1.14)\end{array}$ \\
\hline DEBT90 & $\begin{array}{c}0.002 \\
(0.87)\end{array}$ & 0.564 & $\begin{array}{l}-0.004 \\
\left(-1.92^{*}\right)\end{array}$ & 0.583 & $\begin{array}{c}-0.001 \\
(-0.15)\end{array}$ & 0.204 & $\begin{array}{c}-0.003 \\
(-0.79)\end{array}$ \\
\hline D07 & $\begin{array}{c}-0.002 \\
(-1.50)\end{array}$ & 0.360 & $\begin{array}{l}0.000 \\
(-0.01)\end{array}$ & 0.011 & $\begin{array}{c}-0.002 \\
(-0.52)\end{array}$ & 0.134 & $\begin{array}{c}0.002 \\
(0.43)\end{array}$ \\
\hline $\mathrm{EC}^{+}$ & $\begin{array}{l}-0.154 \\
\left(-3.95^{* *}\right)\end{array}$ & 2.140 & $\begin{array}{c}0.038 \\
(1.28)\end{array}$ & 0.555 & $\begin{array}{l}-0.134 \\
\left(-2.02^{* *}\right)\end{array}$ & 0.942 & $\begin{array}{c}0.173 \\
\left(2.37^{* *}\right)\end{array}$ \\
\hline \multirow[t]{2}{*}{$\mathrm{EC}^{-}$} & $\begin{array}{c}-0.038 \\
(-1.00)\end{array}$ & 0.804 & $\begin{array}{c}-0.016 \\
(-0.49)\end{array}$ & 0.058 & $\begin{array}{c}0.081 \\
(1.38)\end{array}$ & 0.865 & $\begin{array}{l}-0.097 \\
(-1.45)\end{array}$ \\
\hline & \multicolumn{7}{|c|}{ Political interaction effects $S \times I D E O$ (coefficients multiplied with 100) } \\
\hline ELEC & $\begin{array}{l}-0.408 \\
\left(-2.31^{* *}\right)\end{array}$ & 0.367 & $\begin{array}{l}-0.432 \\
\left(-2.25^{* *}\right)\end{array}$ & 1.171 & $\begin{array}{c}-0.395 \\
(-1.31)\end{array}$ & 0.159 & $\begin{array}{c}-0.037 \\
(-0.11)\end{array}$ \\
\hline POLA & $\begin{array}{l}0.432 \\
\left(1.72^{*}\right)\end{array}$ & 0.306 & $\begin{array}{c}-0.008 \\
(-0.03)\end{array}$ & 0.069 & $\begin{array}{c}0.969 \\
\left(2.23^{* *}\right)\end{array}$ & 1.693 & $\begin{array}{l}-0.977 \\
\left(-1.90^{*}\right)\end{array}$ \\
\hline NCP & $\begin{array}{c}0.041 \\
(0.58)\end{array}$ & 0.024 & $\begin{array}{l}0.131 \\
\left(1.92^{*}\right)\end{array}$ & 0.763 & $\begin{array}{c}0.130 \\
(1.09)\end{array}$ & 0.351 & $\begin{array}{c}0.001 \\
(0.01)\end{array}$ \\
\hline
\end{tabular}

Table 6: Estimation results for IDEO interacted with socio-economic and political variables. For further notes see Table 3 . 


\begin{tabular}{|c|c|c|c|c|c|c|c|}
\hline \multicolumn{4}{|c|}{ 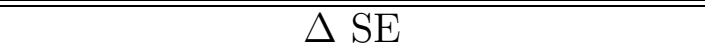 } & \multicolumn{4}{|c|}{ 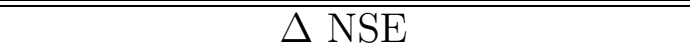 } \\
\hline \multicolumn{2}{|c|}{ fav. EDP } & \multicolumn{2}{|c|}{ unfav. EDP } & \multicolumn{2}{|c|}{ fav. EDP } & \multicolumn{2}{|c|}{ unfav. EDP } \\
\hline$\Delta \mathrm{GDP}^{+}$ & + & $\overline{\Delta \mathrm{GDP}^{-}}$ & ++ & $\Delta \mathrm{GDP}^{+}$ & -- & $\Delta \mathrm{GDP}^{-}$ & + \\
\hline$\Delta \mathrm{UE}^{-}$ & - & $\Delta \mathrm{UE}^{+}$ & -- & $\Delta \mathrm{UE}^{-}$ & + & $\Delta \mathrm{UE}^{+}$ & - \\
\hline$\Delta \mathrm{P} 15^{+}$ & - & $\Delta \mathrm{P} 15^{-}$ & - & $\Delta \mathrm{P} 15^{+}$ & - & $\Delta \mathrm{P} 15^{-}$ & + \\
\hline$\Delta \mathrm{P} 65^{-}$ & ++ & $\Delta \mathrm{P} 65^{+}$ & - & $\Delta \mathrm{P} 65^{-}$ & - & $\Delta \mathrm{P} 65^{+}$ & - \\
\hline$\Delta \mathrm{TRADE}^{+}$ & + & $\Delta \mathrm{TRADE}^{-}$ & - & $\Delta \mathrm{TRADE}^{+}$ & - & $\Delta \mathrm{TRADE}^{-}$ & - \\
\hline$\Delta \mathrm{NX}^{+}$ & + & $\Delta \mathrm{NX}^{-}$ & - & $\Delta \mathrm{NX}^{+}$ & - & $\Delta \mathrm{NX}^{-}$ & + \\
\hline $\mathrm{SURP}^{+}$ & + & $\mathrm{SURP}^{-}$ & + & $\mathrm{SURP}^{+}$ & - & $\mathrm{SURP}^{-}$ & ++ \\
\hline & & DEBT90 & -- & & & DEBT90 & - \\
\hline$-\mathrm{EC}^{-}$ & + & $-\mathrm{EC}^{+}$ & - & $-\mathrm{EC}^{-}$ & - & $-\mathrm{EC}^{+}$ & ++ \\
\hline pos. $\bar{R}^{2}$ & 0.87 & pos. $\bar{R}^{2}$ & 1.13 & pos. $\bar{R}^{2}$ & 0.12 & pos. $\bar{R}^{2}$ & 5.03 \\
\hline neg. $\bar{R}^{2}$ & 0.30 & neg. $\bar{R}^{2}$ & 4.15 & neg. $\bar{R}^{2}$ & 2.43 & neg. $\bar{R}^{2}$ & 0.61 \\
\hline
\end{tabular}

Table 7: Summary for IDEO interacted with socio-economic and political variables for right-wing vs. left-wing governments. 'fav. EDP' and 'unfav. EDP', are short for favourable and unfavourable economic and demographic performance, respectively. ' + ', $('++$ ') and '-' ('-- ', ) indicate with $10 \%$ (5\%) significance that right-wing governments spend more (and reduce less) than their left-wing counterparts in SE and NSE categories. 'pos.' ('neg.') $\bar{R}^{2}$ indicates the total contribution to the partial degree of explanation of positive (negative) impacts of the explanatory variables.

\begin{tabular}{l|cccc|cccc}
\hline \hline & \multicolumn{4}{|c|}{ No trend, AR $(1)$} & \multicolumn{4}{c}{ With trend, AR(1) } \\
\hline & LLC & BD & HS & DH & LLC & BD & HS & DH \\
\hline PE & 2.714 & 1.654 & 1.331 & 2.561 & 0.388 & 0.204 & 0.264 & 0.691 \\
GDP & 3.528 & 1.086 & 0.938 & 1.736 & 0.208 & 0.135 & 0.122 & 0.558 \\
UE & -4.909 & -2.839 & -2.434 & -2.361 & -0.041 & 0.021 & 0.020 & -0.775 \\
DR & -2.575 & -1.859 & -1.650 & -0.766 & -2.589 & 1.649 & -1.630 & 1.031 \\
NX & -0.413 & -0.239 & -0.385 & -0.320 & -0.492 & 0.301 & -0.504 & 0.055 \\
TRADE & 2.217 & 0.619 & 0.387 & 0.517 & 0.275 & 0.140 & 0.073 & 0.900 \\
SURP & -3.721 & -2.279 & -1.899 & -2.245 & -1.461 & 1.013 & -1.053 & 0.622 \\
\hline \hline
\end{tabular}

Table 8: Panel unit root diagnostics. 'LLC', 'BD', 'HS' and 'DH' refer to diagnostics introduced by Levin, Lin and Chu (2002), Breitung and Das (2005), Herwartz and Siedenburg (2008) and Demetrescu and Hanck (2012), respectively. Under suitable assumptions all diagnostics are asymptotically Gaussian under the panel unit root null hypothesis. The $5 \%$ critical value is -1.64 . 'HS' and ' $\mathrm{DH}$ ' have been shown to be robust under time varying covariances and, hence, are robust in contrast to 'LLC' and 'BD'. For notes on the panel composition see Table 2 . 


\begin{tabular}{l|cccc|cccc}
\hline \hline & \multicolumn{4}{|c|}{ Model with PE, GDP, UN } & \multicolumn{4}{c}{ Model with PE, GDP, DR } \\
\hline test & stat & $z$ & $p$ & rob $p$ & stat & $z$ & $p$ & rob $p$ \\
\hline$G_{\tau}$ & -2.452 & -2.08 & .019 & .020 & -2.672 & -3.17 & .001 & .008 \\
$G_{\alpha}$ & -8.467 & 0.48 & .685 & .046 & -8.304 & 0.60 & .726 & .072 \\
$P_{\tau}$ & -10.28 & -2.35 & .009 & .036 & -11.01 & -3.06 & .001 & .016 \\
$P_{\alpha}$ & -6.023 & -0.13 & .449 & .204 & -6.958 & -0.90 & .185 & .084 \\
\hline \hline
\end{tabular}

Table 9: ECM based results (Westerlund 2007) for testing the null hypothesis of no cointegration. Test statistics $G_{\bullet}$ and $P_{\bullet}, \bullet \in\{\tau, \alpha\}$, indicate diagnostics from mean group and pooled models, respectively. Statistics indicated with $\tau$ are derived from standardized mean group or pooled estimators. 'stat' and ' $z$ ' refer to the test statistic before and after standardization. Gaussian and robust bootstrap $p$-values are documented in the columns labelled with denoted ' $p$ ' and 'rob $p$ ', respectively. For notes on the panel composition see Table 2 .

\begin{tabular}{c|cccccc}
\hline \hline & GDP & UE & DR & c & $t$ & $D 07$ \\
\hline MG & 0.467 & 0.999 & -1.689 & 5.133 & 0.386 & 0.085 \\
& $(1.80)$ & $(2.48)$ & $(-1.84)$ & $(2.47)$ & $(0.88)$ & $(4.68)$ \\
\hline \hline
\end{tabular}

Table 10: Mean group estimates of cointegration parameters (MG $t$-ratios in parantheses). UE and DR are in percent, i.e. scaled between 0 and 1 . Coefficients of the linear trend have been multiplied with 100. For notes on the panel composition see Table 2.

\section{Supplementary material}

\begin{tabular}{cc|ccc|cc|cc|cc}
\hline \hline \multicolumn{2}{c}{ GDP } & \multicolumn{2}{c}{ UE } & \multicolumn{2}{c}{ TRADE } & NX & \multicolumn{2}{c}{ SURP } \\
\hline \multicolumn{2}{c}{ Contemporaneous economic performance (growth rates) } \\
\hline$c_{0}$ & $c_{1}$ & $c_{0}$ & $c_{1}$ & $c_{0}$ & $c_{1}$ & $c_{0}$ & $c_{1}$ & $c_{0}$ & $c_{1}$ \\
\hline 0.109 & -0.030 & 0.014 & 0.006 & 0.047 & -0.009 & 0.037 & -0.001 & 0.040 & $-5 \mathrm{E}-05$ \\
$(0.572)$ & $(-0.552)$ & $(0.097)$ & $(0.810)$ & $(0.332)$ & $(-0.444)$ & $(0.266)$ & $(-0.950)$ & $(0.283)$ & $(-0.160)$ \\
\hline \multicolumn{7}{l}{ Lagged economic performance (lagged growth rates) } \\
\hline 0.039 & -0.002 & 0.059 & -0.007 & 0.051 & 0.004 & 0.039 & $9 \mathrm{E}-05$ & 0.037 & $-6 \mathrm{E}-05$ \\
$(0.274)$ & $(-0.788)$ & $(0.416)$ & $(-0.920)$ & $(0.356)$ & $(0.643)$ & $(0.276)$ & $(0.511)$ & $(0.259)$ & $(-0.127)$ \\
\hline
\end{tabular}

Table 11: The Table documents regression results (coefficient estimates and $t$-statistics in parentheses of linea regressions of the form $z_{t}=c_{0}+w_{t} c_{1}+u_{t}$, where $u_{t}$ is an error term, $z_{t}=I D E O_{t}-I D E O_{t-1}$ is the change of government ideology in an election year and $w_{t}$ is a (contemporaneous or lagged) indicator of economic performance. 